\title{
Production, composition, and oxidative stability of milk highly enriched in polyunsaturated fatty acids from dairy cows fed alfalfa protein concentrate or supplemental vitamin $\mathrm{E}$
}

\author{
M.-C. Fauteux, R. Gervais, D. E. Rico, Y. Lebeuf, and P. Y. Chouinard ${ }^{1}$ \\ Département des Sciences Animales, Université Laval, Québec, QC, Canada G1V 0A6
}

\begin{abstract}
Given its elevated content of carotenoids, alfalfa protein concentrates (APC) have the potential to prevent oxidation of milk enriched in polyunsaturated fatty acids. The effects of feeding APC or supplemental vitamin $\mathrm{E}$ on production, composition, and oxidative stability of milk enriched in polyunsaturated fatty acids were evaluated using 6 lactating Holstein cows (224 $\pm 18 \mathrm{~d}$ in milk) in a replicated $3 \times 3$ Latin square (21-d periods, $14 \mathrm{~d}$ for adaptation). Treatment diets contained (dry matter basis) (1) 9\% soybean meal (control, CTL); (2) 9\% soybean meal + $300 \mathrm{IU}$ of vitamin $\mathrm{E} / \mathrm{kg}$ (VitE treatment); or (3) 9\% APC (APC treatment). Cows received a continuous abomasal infusion of $450 \mathrm{~g} / \mathrm{d}$ of linseed oil. As a result, milk fat content of cis-9,cis-12 18:2 increased from $1.08 \pm 0.13$ to $3.9 \pm$ $0.40 \%$ (mean $\pm \mathrm{SD}$ ), whereas cis-9,cis-12,cis-15 18:3 increased from $0.40 \pm 0.04$ to $14.27 \pm 1.81 \%$ during the experimental period compared with the pretrial period. Milk yield tended to be higher for APC $(14.7 \mathrm{~kg} / \mathrm{d})$ compared with CTL $(13.4 \mathrm{~kg} / \mathrm{d})$, and was greater than that for VitE $(13.0 \mathrm{~kg} / \mathrm{d})$. Protein yield was higher in cows fed APC (518 g/d) compared with VitE (445 g/d) but was not different from that in cows fed CTL (483 $\mathrm{g} / \mathrm{d})$. These effects resulted in improved milk $\mathrm{N}$ efficiency in cows fed APC (26.1\% of $\mathrm{N}$ intake secreted in milk) compared with CTL $(23.0 \%)$ and VitE (22.9\%). Feeding APC increased milk fat content of lutein (252 $\mu \mathrm{g} / \mathrm{g})$ compared with CTL $(204 \mu \mathrm{g} / \mathrm{g})$ and VitE (190 $\mu \mathrm{g} / \mathrm{g})$. Milk fat content of vitamin $\mathrm{E}$ was higher for APC $(34.5 \mu \mathrm{g} / \mathrm{g})$ compared with CTL $(19.0 \mu \mathrm{g} / \mathrm{g})$ and tended to be lower than that with VitE $(44.9 \mu \mathrm{g} / \mathrm{g})$. Redox potential of fresh milk from cows fed APC $(152 \mathrm{mV})$ was similar to that of $\operatorname{VitE}(144 \mathrm{mV})$, but lower than that of CTL $(189 \mathrm{mV})$. Treatments had no effect on fresh milk contents of dissolved oxygen (8.1 \pm $1.5 \mathrm{mg} / \mathrm{L})$, and conjugated diene hydroperoxides (2.7
\end{abstract}

Received December 4, 2015

Accepted January 31, 2016

${ }^{1}$ Corresponding author: yvan.chouinard@fsaa.ulaval.ca $\pm 0.5 \mathrm{mmol} / \mathrm{L})$. The concentrations of volatile lipid oxidation products (propanal, hexanal, hept-cis-4-enal, 1-octen-3-one) tended to be decreased by APC relative to CTL, whereas similar values were observed for VitE, except for hexanal, which was reduced by $40 \%$ in VitE. In conclusion, feeding APC to lactating dairy cows could serve as a source of dietary protein that improves dietary $\mathrm{N}$ utilization efficiency, and also as a preharvest technology to increase natural antioxidant levels in milk to limit oxidation.

Key words: alfalfa protein concentrate, carotenoid, polyunsaturated fatty acids, vitamin $\mathrm{E}$

\section{INTRODUCTION}

Current public awareness on the health properties of PUFA, including those of the n-3 family, which are known for their potential disease preventing effects, has increased the interest for dairy products rich in these fatty acids (Ozen et al., 2012; Flock et al., 2013). In this regard, studies have shown positive effects on blood lipid profile in human subjects consuming food products (including milk) from animals fed linseed as a source of n-3 fatty acids (Weill et al., 2002; MalpuechBrugère et al., 2010).

Much research has been done on the potential to modify bovine milk fat through dietary interventions, the major aim being to increase PUFA content and thus, to modulate the nutritional value of dairy products. Adding a rumen bypass supplement of linseed oil to the diet of dairy cows has been proposed as an efficient way to increase the n-3 fatty acids proportion in dairy products (Côrtes et al., 2011). However, the use of linseed oil in dairy cow diets has been limited due to the high sensitivity of PUFA to oxidation. Indeed, oxidation of milk fat has been associated with the development of undesirable flavors (e.g., rancidity) and potentially toxic chemicals (Matumoto-Pintro et al., 2011), which can impair the nutritional and sensory properties of dairy products (Boroski et al., 2012). Vitamin E is currently recommended as a milk antioxidant in dairy cow diets (NRC, 2001). However, other dietary ingredients com- 
monly found have been considered for their content in specific molecules with antioxidant properties. Among these compounds, carotenoids from alfalfa have been studied for their influence on the sensory characteristics of dairy products (Barrefors et al., 1995). Because of their extended system of conjugated double bonds, carotenoids contain a reactive electron-rich system that favors reactions with electrophilic compounds. Consequently, when carotenoids are in contact with oxygen, they tend to autoxidize (van den Berg et al., 2000), a chemical process that leads to the formation of various epoxides, ketones, and aldehydes (Sies and Stahl, 1995).

Alfalfa contains good quality protein and high concentrations of carotenoids. These compounds can be extracted by cold pressing and further concentrated by drying the liquid fraction to obtain an alfalfa protein concentrate (APC), rich in carotenoids (Dang Van et al., 2011). In addition, other specific compounds, such as isoflavones, coumestrol, phytates, L-canavanine, and saponins, have been identified in APC (Gaweł and Grzelak, 2012). As a feedstuff, APC is reported to be a source of low-degradable protein (Lu et al., 1988) and PUFA partially protected against ruminal biohydrogenation (Dang Van et al., 2011; Hurtaud et al., 2013). Additionally, Calderón et al. (2007b) observed that supplying APC in the diet of dairy cows induced an increase in the concentration of carotenoids in plasma and, to a lesser extent, in milk. To our knowledge, the potential of APC supplementation to prevent oxidation of milk enriched in PUFA has not yet been explored. The aim of this study was therefore to evaluate the effects of feeding APC or supplemental vitamin E on production, composition, and oxidative stability of milk from cows receiving a continuous intra-abomasal infusion of linseed oil.

\section{MATERIALS AND METHODS}

\section{Animals and Dietary Treatments}

All procedures performed in this study were approved by the institutional animal care committee based on the current guidelines of the Canadian Council on Animal Care (1993). Six multiparous Holstein cows with rumen fistulas, averaging $224 \pm 18 \mathrm{DIM}$ and $672 \pm 57 \mathrm{~kg}$ of BW (mean $\pm \mathrm{SD}$ ) at the beginning of the trial, were used in a replicated $3 \times 3$ Latin square design. Each experimental period lasted $21 \mathrm{~d}$, with $14 \mathrm{~d}$ for adaptation and $7 \mathrm{~d}$ for data collection. Cows were randomly assigned to square and to experimental diets within each square. Cows were housed in a tiestall barn and had free access to water at all times during the experiment. Treatment diets (Table 1) were formulated to contain (1) $9 \%$ soybean meal (SBM; DM basis, control, CTL diet); (2)
$9 \% \mathrm{SBM}+300 \mathrm{IU}$ of vitamin $\mathrm{E} / \mathrm{kg}$ (VitE diet); and (3) 9\% APC (APC diet; Table 2; Extraluz, Désialis, Châlons-en-Champagne, France). All cows received a continuous abomasal infusion of linseed oil (containing $22.4 \%$ cis-9 18:1, $18.2 \%$ cis- 9 ,cis-12 18:2, and $44.8 \%$ cis-9, cis-12,cis-15 18:3, proportion of total fatty acids) at a rate of $450 \mathrm{~g} / \mathrm{d}$ from the start of the experiment. Infusions were delivered to the abomasum using a peristaltic pump (Flexiflo Patrol Pump; Abbott Nutrition Canada, Saint-Laurent, QC, Canada) equipped with a pump set (\#0M306030; Abbott Nutrition Canada) and an infusion line (Nalgene tubing $4.8 \mathrm{~mm}$ i.d., $1.6 \mathrm{~mm}$ wall; Fisher Scientific, Ottawa, ON, Canada). This line extended through the rumen fistula and sulcus omasi into the abomasum, where it was secured by a $10-\mathrm{cm}$ rubber flange and a perforated Nalgene plastic bottle $(60 \mathrm{~mL})$ attached to the end of the tubing (Gressley et al., 2006). Placement of the tubing within the abomasum was confirmed daily by palpation.

Based on initial feed ingredient composition, diets were formulated to be isonitrogenous and to meet or exceed the National Research Council requirements (NRC, 2001; Table 1). Diets were fed as TMR (85:15 forage:concentrate ratio) at $1000 \mathrm{~h}$ daily, and the amount offered was adjusted based on the previous day's intake to allow for $10 \%$ refusals. Silages were sampled every week and dried for $72 \mathrm{~h} \mathrm{~d}$ at $55^{\circ} \mathrm{C}$ to determine DM concentration, and to adjust the composition of treatment diets on an as-fed basis.

\section{Experimental Measurements and Sampling}

Body weight was measured at $0930 \mathrm{~h}$ on d 19, 20, and 21 of each period. Refusals were weighed daily just before feeding. Samples of TMR and refusals were collected from d 18 to 21 of each period, composited by treatment within period, and dried at $55^{\circ} \mathrm{C}$ for $3 \mathrm{~d}$ to determine DM. Dry samples were ground to pass a 1-mm screen using a Cyclotec mill (model 1093; Foss, Eden Prairie, MN) and kept frozen at $-20^{\circ} \mathrm{C}$ for further analyses.

Ruminal Content. Rumen fluid was collected from the ventral sac through the fistula of cows on d 20 (square 1) and 21 (square 2) at $0,1,2,4,6$, and $8 \mathrm{~h}$ relative to feeding time. Rumen fluid was immediately filtered through 4 layers of cheesecloth, and $\mathrm{pH}$ was recorded using a pHTestr 30 (Oakton Instruments, Vernon Hills, IL). Rumen fluid samples $(10 \mathrm{~mL})$ were then stabilized in $0.2 \mathrm{~mL}$ of sulfuric acid (50\%) and frozen at $-20^{\circ} \mathrm{C}$.

Blood. Blood was collected on d 18 and 19 of each period twice daily (1000 and $1400 \mathrm{~h})$. Blood samples were withdrawn from the coccygeal vessel into evacuated plasma separation tubes containing EDTA (Vacu- 
Table 1. Ingredients, chemical composition, and fatty acid profile of experimental diets

\begin{tabular}{|c|c|c|c|}
\hline \multirow[b]{2}{*}{ Item } & \multicolumn{3}{|c|}{ Treatment $^{1}$} \\
\hline & CTL & VitE & $\mathrm{APC}$ \\
\hline \multicolumn{4}{|l|}{ Ingredient, $\%$ of DM } \\
\hline Timothy silage & 86.8 & 86.8 & 86.8 \\
\hline Ground barley & 2.0 & 2.0 & 2.0 \\
\hline Soybean meal & 9.1 & 9.1 & - \\
\hline Alfalfa protein concentrate ${ }^{2}$ & - & - & 9.1 \\
\hline Vitamin $\mathrm{E}^{3}$ & - & 0.03 & - \\
\hline Mineral and vitamin $\operatorname{mix}^{4}$ & 2.0 & 2.0 & 2.0 \\
\hline \multicolumn{4}{|l|}{ Chemical composition } \\
\hline DM, $\%$ as fed & 39.3 & 38.2 & 38.1 \\
\hline $\mathrm{OM}, \%$ of $\mathrm{DM}$ & 91.9 & 92.0 & 91.7 \\
\hline NDF, $\%$ of DM & 57.9 & 59.1 & 60.8 \\
\hline $\mathrm{ADF}, \%$ of $\mathrm{DM}$ & 38.8 & 39.3 & 39.7 \\
\hline $\mathrm{CP}, \%$ of $\mathrm{DM}$ & 11.3 & 10.7 & 11.0 \\
\hline Ether extract, \% of DM & 2.7 & 2.7 & 3.1 \\
\hline $\mathrm{NE}_{\mathrm{L}},{ }^{5} \mathrm{Mcal} / \mathrm{kg}$ of DM & 1.30 & 1.30 & 1.21 \\
\hline \multicolumn{4}{|l|}{ Fatty acid, mg/g of DM } \\
\hline $14: 0$ & 0.10 & 0.10 & 0.12 \\
\hline 16:0 & 3.50 & 3.50 & 4.13 \\
\hline cis-9 16:1 & 0.11 & 0.11 & 0.12 \\
\hline 18:0 & 0.90 & 0.90 & 1.02 \\
\hline cis-9 18:1 + cis-11 18:1 & 1.68 & 1.65 & 1.71 \\
\hline cis-9,cis-12 18:2 & 3.62 & 3.67 & 3.68 \\
\hline cis-9,cis-12,cis-15 18:3 & 5.20 & 5.31 & 6.30 \\
\hline Total & 15.1 & 15.2 & 17.1 \\
\hline \multicolumn{4}{|l|}{ Antioxidant, $\mu \mathrm{g} / \mathrm{g}$ of $\mathrm{DM}$} \\
\hline Lutein & 44.0 & 51.2 & 68.1 \\
\hline Zeaxanthin & 24.9 & 27.8 & 28.0 \\
\hline$\beta$-Carotene & 18.2 & 20.5 & 31.6 \\
\hline Vitamin E & 27.9 & 221.7 & 25.6 \\
\hline
\end{tabular}

${ }^{1} \mathrm{CTL}=$ control; VitE $=$ vitamin $\mathrm{E} ; \mathrm{APC}=$ alfalfa protein concentrate.

${ }^{2}$ Extraluz (Désialis, Châlons-en-Champagne, France).

${ }^{3}$ DL- $\alpha$-tocopheryl-acetate (Aliments Breton Inc., St-Bernard, QC, Canada).

${ }^{4}$ For CTL and VitE treatments: $9.2 \% \mathrm{Ca}, 2.8 \% \mathrm{P}, 0.2 \% \mathrm{Mg}, 0.2 \% \mathrm{~K}$, $8.5 \% \mathrm{Na}, 5.1 \% \mathrm{Cl}, 0.3 \% \mathrm{~S}, 320 \mathrm{mg} / \mathrm{kg} \mathrm{Cu}, 1,232 \mathrm{mg} / \mathrm{kg} \mathrm{Zn}, 14.4 \mathrm{mg} /$ $\mathrm{kg}$ Co, $127,687 \mathrm{IU} / \mathrm{kg}$ vitamin $\mathrm{A}$, and $53,202 \mathrm{IU} / \mathrm{kg}$ vitamin D. For APC treatment: $2.0 \% \mathrm{P}, 0.2 \% \mathrm{Mg}, 5.4 \% \mathrm{~K}, 8.0 \% \mathrm{Na}, 5.0 \% \mathrm{Cl}, 0.3 \%$ $\mathrm{S}, 315 \mathrm{mg} / \mathrm{kg} \mathrm{Cu}, 1,216 \mathrm{mg} / \mathrm{kg} \mathrm{Zn}, 14.2 \mathrm{mg} / \mathrm{kg} \mathrm{Co}, 126,596 \mathrm{IU} / \mathrm{kg}$ vitamin $\mathrm{A}$, and $52,748 \mathrm{IU} / \mathrm{kg}$ vitamin $\mathrm{D}$.

${ }^{5}$ Estimated based on NRC (2001) and excluding the $\mathrm{NE}_{\mathrm{L}}$ provided by $450 \mathrm{~g} / \mathrm{d}$ of linseed oil abomasally infused.

tainer 366430, Becton Dickinson, Franklin Lakes, NJ). Blood was placed on ice until centrifuged at $956 \times g$ for $15 \mathrm{~min}$ at $4^{\circ} \mathrm{C}$. The supernatants were transferred to microtubes and frozen at $-20^{\circ} \mathrm{C}$ for later analysis.

Milk. Cows were milked at 0700 and $1700 \mathrm{~h}$ daily. Milk production was measured using calibrated milk meters (Flomaster Pro, DeLaval, Tumba, Sweden), and milk samples were collected at each milking from d 18 to 20. A first subsample was preserved in bronopol and stored at $4^{\circ} \mathrm{C}$ until analyzed for milk composition. A second subsample without preservative was stored at $-20^{\circ} \mathrm{C}$ for later fatty acid, carotenoid, and vitamin $\mathrm{E}$ determinations. Additional milk samples without preservative were collected on 3 consecutive days before
Table 2. Chemical composition of alfalfa protein concentrate

\begin{tabular}{lc}
\hline Item & Concentration \\
\hline $\mathrm{DM}, \%$ as fed & 98.3 \\
OM, \% of DM & 88.0 \\
$\mathrm{NDF}, \%$ of DM & 12.9 \\
ADF, \% of DM & 2.8 \\
CP, \% of DM & 50.8 \\
Ether extract, \% of DM & 7.0 \\
Fatty acid, mg/g of DM & \\
$14: 0$ & 0.5 \\
$16: 0$ & 11.1 \\
cis-9 16:1 & 0.2 \\
cis:0 $18: 1+$ cis-11 18:1 & 1.6 \\
cis-9, cis-12 18:2 & 1.9 \\
cis-9, cis-12,cis-15 18:3 & 10.0 \\
Total & 22.9 \\
\hline
\end{tabular}

the start of the feeding trial for fatty acid analysis to assess the effect of postruminal supply of linseed oil.

Additional milk samples were collected from individual cows on d 18 a.m. (square 1) or 19 a.m. (square 2), and immediately cooled on ice at $4^{\circ} \mathrm{C}$ until processed for determination of oxidative stability. These samples were transported at the Université Laval pilot plant in 1-L stainless steel cans. Milk was heated at $50^{\circ} \mathrm{C}$, homogenized at $24 \mathrm{MPa}$ (EmulsiFlex-C50, Avestin, Ottawa, ON, Canada), and cooled at $4^{\circ} \mathrm{C}$. Samples were supplemented with $0.001 \% \mathrm{Fe}\left(\right.$ as $\mathrm{FeSO}_{4}$ ) to induce oxidation and sodium azide $(0.02 \%)$ to prevent microbial growth (Giroux et al., 2008) and were stored at $4^{\circ} \mathrm{C}$ in a cabinet under light exposure using fluorescent lamps (warm white, linear T12, $40 \mathrm{~W}$; Lumisolution Inc., Québec, QC, Canada). Two series of glass tubes (7.55 $\times 2.25 \mathrm{~cm}$ and $9.50 \times 2.70 \mathrm{~cm}$ ) containing 6 and $12 \mathrm{~mL}$, respectively, of homogenized milk were capped and laid horizontally at $30 \mathrm{~cm}$ from the light source. Samples in small tubes were analyzed after $0,2,4,7$, and $10 \mathrm{~d}$ for hexanal, propanal, hept-cis-4-enal, and 1-octen-3-one. Samples in large tubes were analyzed after $0,1,2,3,4$, 7 , and $10 \mathrm{~d}$ for conjugated diene hydroperoxides, dissolved oxygen, and redox potential. The same analyses were performed on fresh nonhomogenized milk at $\mathrm{d} 0$.

On d 20 of each period, milk from 2 consecutive milkings was collected from each cow and pooled by treatment in 250-L refrigerated bulk tanks. Once the pool reached $4^{\circ} \mathrm{C}$ after the second milking, milk was immediately transferred to the Université Laval pilot plant for butter manufacture. Briefly, raw milk was separated into skim milk and cream at $50^{\circ} \mathrm{C}$ with the use of a cream separator (model \#619; De Laval, Peterborough, ON, Canada). Cream was cooled at $4^{\circ} \mathrm{C}$ and stored at $-20^{\circ} \mathrm{C}$ until processed. At the time of butter production, the cream was thawed and churned at $4^{\circ} \mathrm{C}$ using a KitchenAid mixer (model Classic Plus, KitchenAid, St. 
Joseph, MI). The buttermilk was separated from the butter kernels by draining through cheesecloth. Butter was pressed to remove excess buttermilk and mixed for 5 min. Butter samples were stored in white plastic cups at $-80^{\circ} \mathrm{C}$ until analyzed.

\section{Feed Analyses}

All TMR and refusals were analyzed according to the following methods: residual moisture (method 934.01; AOAC International, 2005), ADF (Ankom Technology, Fairport, NY; method 5: ADF in feeds - filter bag technique for A200; solutions as in method 973.18; AOAC International, 2005), NDF (Ankom Technology method 6: NDF in feeds-filter bag technique for A200; solutions as in Van Soest et al., 1991 with the inclusion of heat-stable $\alpha$-amylase $), \mathrm{CP}(\mathrm{N} \times 6.25$; method 990.03; AOAC International, 2005), and ether extract (method 920.39; AOAC International, 2005).

Dietary fatty acids were directly transesterified and FAME were extracted following the method described by Jenkins (2010) with modifications (Villeneuve et al., 2013). Fatty acid profile was determined with a gas chromatograph (Clarus 680; Perkin Elmer, Waltham, MA) equipped with a polar capillary column (HP-Innowax $30-\mathrm{m}$ length, $0.320 \mathrm{~mm}$ i.d., $0.25 \mu \mathrm{m}$ film thickness; Agilent Technologies Canada Inc., Mississauga, ON, Canada), and a flame-ionization detector. At the time of the sample injection, the column temperature was maintained at $185^{\circ} \mathrm{C}$ for $0.5 \mathrm{~min}$, and then increased at $3^{\circ} \mathrm{C} / \mathrm{min}$ to $220^{\circ} \mathrm{C}$. Inlet and detector temperatures were at 240 and $250^{\circ} \mathrm{C}$, respectively, and the split ratio was 50:1. The flow rate for hydrogen carrier gas was 1 $\mathrm{mL} / \mathrm{min}$.

Additional fresh TMR samples were thawed, composited by period, and lyophilized (VirTual 50L, VirTis SP Scientific, Stone Ridge, NY). Carotenoids and vitamin E were extracted from dried samples (500 mg) in diethyl ether after saponification. Briefly, samples were saponified $\left(4 \% \mathrm{KOH}\right.$ in methanol) at $100^{\circ} \mathrm{C}$ for $30 \mathrm{~min}$ in presence of butylated hydroxytoluene (200 $\mu \mathrm{g})$. A 2-phase separation was achieved using a diethyl ether:water solution (50:50, vol/vol). Samples were vortexed for $1 \mathrm{~min}$ and the top layer recovered in a new extraction tube. Extractions were performed 3 times. The extract was then evaporated under $\mathrm{N}_{2}$, and dissolved in $1.0 \mathrm{~mL}$ of dichloromethane:methanol (65:35, vol/ vol). Samples were then filtered $(0.2-\mu \mathrm{m}$ polytetrafluoroethylene; VWR International, Ville Mont-Royal, QC, Canada) and transferred to HPLC vials. A volume of $15 \mu \mathrm{L}$ was injected into an HPLC (1200 series, Agilent Technologies Canada Inc.) equipped with 2 C18 column in series (column 1: $4.6 \times 150 \mathrm{~mm}, 3-\mu \mathrm{m}$ particle size; column 2: $4.6 \times 250 \mathrm{~mm}, 5-\mu \mathrm{m}$ particle size; Advanced Chromatography Technologies, Aberdeen, UK) coupled with a 5- $\mu \mathrm{m}$ guard column (Advanced Chromatography Technologies). The isocratic mobile phase was a solution ( $\mathrm{vol} / \mathrm{vol}$ ) of $70 \%$ acetonitrile, $15 \%$ methanol (containing $50 \mathrm{mM}$ ammonium acetate), 10\% dichloromethane, and $5 \%$ water, and the flow rate was $2 \mathrm{~mL} /$ min. Carotenoid detection was performed at $450 \mathrm{~nm}$ with a G1315D photodiode array detector (Agilent Technologies Canada Inc.). Detection of vitamin E was performed with a G1321B fluorescence detector (Agilent Technologies Canada Inc.) with an excitation wavelength of $212 \mathrm{~nm}$ and an emission wavelength of $340 \mathrm{~nm}$.

\section{Rumen Fluid Analyses}

For analysis of $\mathrm{NH}_{3}-\mathrm{N}$ and VFA, samples of ruminal fluid were thawed at room temperature and centrifuged at $25,200 \times g$ for $15 \mathrm{~min}$ at $4^{\circ} \mathrm{C}$, and the supernatants were transferred to microtubes. Concentration of $\mathrm{NH}_{3^{-}}$ $\mathrm{N}$ in ruminal fluid was determined as in Weatherburn (1967) using a Varioskan spectrophotometer (type 3001, cat. no 5250010, Thermo Electron Corporation, Vantaa, Finland) at $625 \mathrm{~nm}$. The profile of ruminal VFA was determined with a gas chromatograph (Agilent 6890N; Agilent Technologies Canada Inc.) equipped with a DB FFAP capillary column $(30 \mathrm{~m} \times 0.25 \mathrm{~mm}$ i.d. $\times$ $0.25 \mu \mathrm{m}$ film; Agilent Technologies Canada Inc.), and a flame-ionization detector. The split ratio was 25:1. At the time of the sample injection, the column temperature was $80^{\circ} \mathrm{C}$, maintained for 0.5 min followed by a first increase to $180^{\circ} \mathrm{C}$ at $10^{\circ} \mathrm{C} / \mathrm{min}$, followed by a second increase to $220^{\circ} \mathrm{C}$ at $30^{\circ} \mathrm{C} / \mathrm{min}$. The temperature was then maintained at $220^{\circ} \mathrm{C}$ for 2 min. All ruminal fluid samples were assayed in triplicate.

\section{Plasma Analyses}

Plasma carotenoid analyses were based on the protocol used by Lyan et al. (2001). All extractions were performed at room temperature and under low light. Briefly, $0.6 \mathrm{~mL}$ of ethanol and $1.2 \mathrm{~mL}$ of hexane were added to $0.6 \mathrm{~mL}$ of plasma, and samples were vortexed for $30 \mathrm{~s}$. Samples were then centrifuged at $500 \times g$ for $45 \mathrm{~s}$, the top layer was removed, and this process was performed 2 additional times. The extract was evaporated under $\mathrm{N}_{2}$, and dissolved in $0.5 \mathrm{~mL}$ of dichloromethane:methanol (65:35, vol/vol). The samples were then filtered (0.2- $\mu \mathrm{m}$ polytetrafluoroethylene) and transferred into HPLC vials. Carotenoid and vitamin $\mathrm{E}$ detection was performed by HPLC as previously described for feeds. 
Plasma color index was assessed using a Genesys 10S UV-VIS spectrophotometer (Thermo Electron Scientific Instruments LLC, Madison, WI) according to the method described by Nozière et al. (2006b). Briefly, the color index was determined as the area under the absorbance spectra (between 450 and $530 \mathrm{~nm}$ ) when reflectance at $530 \mathrm{~nm}$ was set equal to zero.

\section{Milk Analyses}

Milk fat, true protein, anhydrous lactose, SCC, and MUN concentrations were determined on samples with preservative by mid-infrared analysis at Valacta (Dairy Production Center of Expertise, Québec and Atlantic Provinces, Ste-Anne-de-Bellevue, QC, Canada). Analyses were performed using a Foss MilkoScan FT 6000 for determination of milk components, combined with a Fossomatic FC for SCC analysis (Foss, Hillerød, Denmark). Results from the 6 consecutive milkings were composited proportionally to milk yield to obtain one value per cow and period before statistical analysis. The second set of subsamples, without preservative, from individual cows was used to determine milk fatty acid composition. Before lipid extraction, milk was thawed, and samples from the 6 consecutive milkings were composited proportionally to milk yield as previously described. Milk fatty acid profiles were determined according to the procedure described by Boivin et al. (2013).

For the analysis of carotenoids and vitamin E, previously frozen milk samples were thawed in a water bath at $37^{\circ} \mathrm{C}$. Tubes were covered with aluminum foil at all times to minimize light exposure. A volume of $5 \mathrm{~mL}$ of milk was saponified $(11 \% \mathrm{KOH}$ in a $50: 50$ ethanol:water solution; wt/wt) at $37^{\circ} \mathrm{C}$ for $90 \mathrm{~min}$ in presence of vitamin $\mathrm{C}(1 \mathrm{~g})$. Extraction of carotenoids and vitamin $\mathrm{E}$ was performed by adding $5 \mathrm{~mL}$ of hexane and vortexing for $30 \mathrm{~s}$. The top layer was then transferred into a new extraction tube, and hexane extraction was performed 2 additional times. The extract was then evaporated under $\mathrm{N}_{2}$ and dissolved in $0.8 \mathrm{~mL}$ of dichloromethane:methanol (65:35; vol/vol). Samples were then filtered (0.2- $\mu \mathrm{m}$ polytetrafluoroethylene) and transferred to HPLC vials. Analysis of milk carotenoids and vitamin E by HPLC was conducted as described earlier.

The analysis of volatile lipid oxidation products in fresh, and light-exposed milk samples was performed in triplicate using the solid-phase microextraction (SPME) technique with a Combi PAL autosampler (CTC Analytics, Zwingen, Switzerland) attached to an Agilent $6890 \mathrm{~N}$ gas chromatograph with 5973 inert mass spectrometry detection (Agilent Technologies Canada
Inc.), as described by Villeneuve et al. (2013), with modifications. Briefly, the sample pre-equilibration was modified to $40^{\circ} \mathrm{C}$ for $5 \mathrm{~min}$. The fiber was exposed to the headspace at the same temperature and agitation for $45 \mathrm{~min}$. Volatile compounds were separated with an Optima-Wax column $(60 \mathrm{~m} \times 0.25 \mathrm{~mm}$, film thickness $0.25 \mu \mathrm{m}$; Macherey-Nagel Inc., Bethlehem, PA). The oven temperature was held at $35^{\circ} \mathrm{C}$ for $2 \mathrm{~min}$, and then increased at a rate of $5^{\circ} \mathrm{C} / \mathrm{min}$ until $140^{\circ} \mathrm{C}$, and then up to $250^{\circ} \mathrm{C}$ at a rate of $20^{\circ} \mathrm{C} / \mathrm{min}$. At that point, the temperature was held at $250^{\circ} \mathrm{C}$ for $22.5 \mathrm{~min}$. The selected ion monitoring was used as data acquisition mode. The compounds in the milk samples were identified by comparing retention times and target ions [propanal: mass to charge ratio $(m / z) 57,58,59$; hexanal: $m / z 44,56$, 72; hept-cis-4-enal: $\mathrm{m} / z$ 41, 55,68 ; 1-octen-3-one: $\mathrm{m} / \mathrm{z}$ $55,70,97]$ of authentic standards spiked to milk. The relative concentrations of individual compounds were determined by comparing the peak area of the compounds in each chromatogram with that of the added hexanal- $\delta 12$ standard $(100 \mu \mathrm{L} ; 0.8 \mathrm{mg} / \mathrm{mL})$ and considering the relative response factors of each compound studied obtained using calibration curves. Standards of volatile compounds were obtained from Sigma Aldrich (Oakville, ON, Canada; hexanal, hept-cis-4-enal, 1-octen-3-one) and Fisher Scientific Co. (Pittsburgh, PA; propanal). Standard of hexanal- $\delta 12$ was obtained from C/D/N Isotopes Inc. (Pointe-Claire, QC, Canada).

Conjugated diene hydroperoxides were determined as described by Kiokias et al. (2006) with some modifications. Samples $(20 \mu \mathrm{L})$ of milk were diluted in 2.5 $\mathrm{mL}$ of isooctane:2-propanol (2:1 vol/vol) and mixed for $30 \mathrm{~s}$. The mixture was filtered through a $0.2-\mu \mathrm{m}$ polyvinylidene fluoride filter (VWR International). The absorbance of the filtrate was measured against an isooctane:2-propanol blank at $232 \mathrm{~nm}$ with a Genesys $10 \mathrm{~S}$ UV-VIS spectrophotometer (Thermo Fisher Scientific). The molar absorptivity of cis-9,cis-12 18:2 (molar extinction coefficient, $\varepsilon=26,000$ ) was used to calculate the concentration of conjugated diene hydroperoxide. Redox potential was measured on the same samples with an Orion epoxy refillable ORP/ATC triode (No. 9180BNMD; Thermo Fisher Scientific) filled with oxidation-reduction potential (ORP) solution (No. 900011; Thermo Fisher Scientific). This electrode was connected to a portable $\mathrm{pH} / \mathrm{mV}$ meter (Orion Star A321; Thermo Fisher Scientific). The electrode reading was verified with a standard solution of potassium iodide having an ORP of $+220 \mathrm{mV}$ at $25^{\circ} \mathrm{C}$ (No. 967901; Thermo Fisher Scientific). The reading was recorded after $10 \mathrm{~min}$ of stable measurement. Finally, dissolved oxygen concentration was determined as described by Haratifar et al. (2011). 


\section{Color Index of Butter}

Color was determined in triplicate at $21^{\circ} \mathrm{C}$ on butter using a chromameter (Minolta CR-300, Konica Minolta Sensing Inc., Osaka, Japan) to determine lightness $\left(\mathrm{L}^{*}\right)$, green-red color $\left(\mathrm{a}^{*}\right)$, and blue-yellow color $\left(\mathrm{b}^{*}\right)$ values, according to the method described by Nozière et al. (2006b).

\section{Statistical Analysis}

Data were first analyzed with the MIXED procedure of SAS (SAS Institute Inc., Cary, NC) as a duplicated $3 \times 3$ Latin square design according to the following model:

$$
Y_{i j k l}=\mu+T_{i}+P_{j}+C_{k}+S_{l}+\varepsilon_{i j k l}
$$

where $Y_{i j k l}$ is the individual observation, $\mu$ the overall mean, $T_{i}$ the fixed effect of treatment ( $i=1$ to 3$), P_{j}$ the fixed effect of period ( $j=1$ to 3 ), $C_{k}$ the random effect of cow ( $k=1$ to 6$), S_{l}$ the random effect of square $(l=1,2)$ and $\varepsilon_{i j k l}$ the residual error terms, and where the subject of the repeated statement was cow within square. The covariance structure selection between autoregressive 1, compound symmetry and variance components was based on the Akaike's information criterion. Because no square effect was observed, it was retrieved from the model, and data were analyzed according to the following model:

$$
Y_{i j k l}=\mu+T_{i}+P_{j}+C_{k}+\varepsilon_{i j k l}
$$

The following preplanned contrasts were used to test the effects of treatment diets: APC versus CTL, and APC versus VitE. For variables where repeated measures were recorded, data were analyzed according to the following model:

$$
Y_{i j k l}=\mu+T_{i}+P_{j}+C_{k}+H_{l}+(T \times H)_{i l}+\varepsilon_{i j k l},
$$

where $H_{l}$ is the effect of sampling time and $(T \times H)_{i l}$ the effect of the interaction between treatment and time of sampling. Cow was considered as a random effect, the subject of the repeated measurements was cow (period $\times$ treatment), and the spatial covariance structure $\mathrm{SP}(\mathrm{POW})$ was used to estimate covariances. When an effect of sampling time or a treatment $\times$ sampling time interaction was detected, linear and quadratic contrasts for sampling time effect were performed. Because there were no sampling time $\times$ treatment interactions for rumen fluid parameters, mean values were combined for statistical analysis according to the model previously described. The preplanned contrasts listed above were used to test the effects of treatment diets at each time point. Differences between treatments were declared at $P \leq 0.05$, and tendencies from $P>0.05$ to $P<0.15$.

\section{RESULTS AND DISCUSSION}

\section{Animal Performance and Ruminal Fermentation}

Body weight and DMI of cows fed APC were not different compared with cows receiving CTL or VitE (Table 3). In contrast, cows receiving APC produced more milk and tended to produce more ECM and FCM compared with VitE. A similar tendency was observed when milk yield (actual and energy-corrected) of cows fed APC was compared with CTL. These results are in contrast to those from the study by Lu et al. (1988), who observed no difference in milk yield when comparing diets with APC and SBM as protein supplements in dairy cows. Hurtaud et al. (2013) reported a tendency for lower milk yield in cows fed APC relative to extruded linseed meal, but no effects of treatments on DMI. In the current experiment, milk fat was not affected by treatments, but lactose yield was increased when cows received APC compared with CTL $(P=$ 0.07) and VitE.

Cows fed APC secreted more milk protein than those fed VitE, which resulted in an improved milk $\mathrm{N}$ efficiency in cows fed APC compared with CTL and VitE (Table 3). This is in contrast to Hurtaud et al. (2013), who reported a tendency for higher milk protein content but no effect of APC on milk protein yield. Treatments in the present experiment were designed to be isonitrogenous (Table 1). Soybean meal, as the main protein source in CTL and VitE dietary treatments, was totally replaced by Extraluz (Désialis) in the APC diet. Rumen $\mathrm{NH}_{3} \mathrm{~N}$ (Table 4) and MUN (Table 3) were decreased when cows received APC compared with CTL. Lower MUN was also observed in cows fed the APC diet compared with the VitE diet. Blood urea nitrogen is a reflection of protein metabolism in ruminants, and high concentrations are predictive of suboptimal utilization of dietary N (Nousiainen et al., 2004). It is well established that urea concentrations in blood and milk are positively correlated (Oltner et al., 1985). Therefore, differences in rumen $\mathrm{NH}_{3}-\mathrm{N}$ and MUN among treatments observed in the current trial could be explained by the differences in rumen degradability between SBM and APC protein. Indeed, $\mathrm{N}$ degradability in the rumen of lactating dairy cows has been reported to be lower for APC (47\%) compared with SBM (57\%; Lu et al., 1988). Lower ruminal degradability of protein could be attributed to heat treatment applied during the drying process of alfalfa juice extract. Reduced MUN was also reported by Dang Van et al. (2011), in a comparison 
Table 3. Effect of experimental diets on BW, intake of nutrients, and milk yield and composition

\begin{tabular}{|c|c|c|c|c|c|c|}
\hline \multirow[b]{2}{*}{ Item } & \multicolumn{3}{|c|}{ Treatment $^{1}$} & \multirow[b]{2}{*}{ SEM } & \multicolumn{2}{|c|}{$P$-value } \\
\hline & CTL & VitE & $\mathrm{APC}$ & & APC vs. CTL & APC vs. VitE \\
\hline $\mathrm{BW}, \mathrm{kg}$ & 688 & 680 & 684 & 15 & 0.38 & 0.37 \\
\hline DMI, kg/d & 18.6 & 17.0 & 18.0 & 0.5 & 0.42 & 0.16 \\
\hline \multicolumn{7}{|l|}{ Milk yield } \\
\hline Actual, kg/d & 13.4 & 13.0 & 14.7 & 1.9 & 0.04 & 0.09 \\
\hline $4 \% \mathrm{FCM}^{2}{ }^{2} \mathrm{~kg} / \mathrm{d}$ & 13.9 & 13.7 & 15.2 & 2.0 & 0.16 & 0.11 \\
\hline $\mathrm{ECM},{ }^{3} \mathrm{~kg} / \mathrm{d}$ & 13.8 & 13.4 & 15.0 & 1.9 & 0.15 & 0.07 \\
\hline \multicolumn{7}{|l|}{ Milk fat } \\
\hline Content, \% & 4.30 & 4.37 & 4.23 & 0.10 & 0.49 & 0.20 \\
\hline Yield, g/d & 571 & 567 & 619 & 80 & 0.22 & 0.19 \\
\hline \multicolumn{7}{|l|}{ Milk protein } \\
\hline Content, \% & 3.66 & 3.56 & 3.59 & 0.17 & 0.28 & 0.68 \\
\hline Yield, g/d & 483 & 445 & 518 & 59 & 0.19 & 0.02 \\
\hline \multicolumn{7}{|l|}{ Milk lactose } \\
\hline Content, \% & 4.39 & 4.31 & 4.46 & 0.07 & 0.34 & 0.07 \\
\hline Yield, g/d & 588 & 570 & 655 & 86 & 0.07 & 0.03 \\
\hline MUN, mg/dL & 13.5 & 12.8 & 11.3 & 0.6 & 0.01 & 0.05 \\
\hline $\mathrm{SCC}, \times 10^{3}$ cells $/ \mathrm{mL}$ & 137 & 195 & 127 & 60 & 0.79 & 0.09 \\
\hline Milk $\mathrm{N}, \%$ of $\mathrm{N}$ intake & 23.0 & 22.9 & 26.1 & 2.5 & 0.04 & 0.04 \\
\hline
\end{tabular}

of diets with APC and SBM as protein sources. These differences in rumen $\mathrm{N}$ metabolism could have resulted in an improved utilization of dietary $\mathrm{N}$, which would explain the higher milk $\mathrm{N}$ efficiency observed in the current study when cows received APC.

Vitamin E supplementation has been reported to reduce ammonia production or improve rumen ammonia utilization in dairy cows. Kay et al. (2005) observed a decrease of approximately $11 \%$ in plasma urea concentration when providing late-lactating dairy cows with $10,000 \mathrm{IU} / \mathrm{d}$ of vitamin $\mathrm{E}$. In contrast, under in vitro conditions, Naziroğlu et al. (2002) reported an increase in rumen $\mathrm{NH}_{3}-\mathrm{N}$ with an increase in vitamin $\mathrm{E}$ supplementation of ruminal fluid. In the present study, feeding vitamin $\mathrm{E}$ to dairy cows appeared to have affected rumen $\mathrm{N}$ metabolism, as depicted by rumen $\mathrm{NH}_{3}-\mathrm{N}$ and MUN concentrations of cows fed VitE, which were intermediary between CTL and APC. However, these results did not translate into improved milk $\mathrm{N}$ efficiency.

Dietary treatments had no effect on straight-chain VFA (Table 4). However, a lower isovalerate concentration was observed with APC compared with the CTL and VitE diets. Similar numerical differences were observed for ruminal concentration of isobutyrate. Through microbial decarboxylation and deamination in the rumen, branched-chain AA serve as precursors to the branched-chain VFA such as isobutyrate and isovalerate (Köster et al., 1996). Therefore, lower ruminal isovalerate concentrations on APC diet may reflect a decrease in protein degradation as mentioned

Table 4. Effect of experimental diets on ruminal $\mathrm{pH}, \mathrm{NH}_{3}-\mathrm{N}$, and VFA content

\begin{tabular}{|c|c|c|c|c|c|c|}
\hline \multirow[b]{2}{*}{ Item } & \multicolumn{3}{|c|}{ Treatment $^{1}$} & \multirow[b]{2}{*}{ SEM } & \multicolumn{2}{|c|}{$P$-value } \\
\hline & CTL & VitE & $\mathrm{APC}$ & & APC vs. CTL & APC vs. VitE \\
\hline $\mathrm{pH}$ & 6.71 & 6.71 & 6.72 & 0.07 & 0.80 & 0.88 \\
\hline $\mathrm{NH}_{3}-\mathrm{N}, \mathrm{mg} / \mathrm{dL}$ & 9.19 & 7.88 & 6.72 & 0.54 & 0.01 & 0.16 \\
\hline \multicolumn{7}{|l|}{ VFA, mmol/L } \\
\hline Acetate & 73.1 & 72.8 & 74.5 & 5.0 & 0.76 & 0.72 \\
\hline Propionate & 19.6 & 18.4 & 18.6 & 1.1 & 0.47 & 0.83 \\
\hline Butyrate & 9.0 & 9.2 & 9.1 & 0.6 & 0.98 & 0.85 \\
\hline Isobutyrate & 1.0 & 1.0 & 0.9 & 0.1 & 0.31 & 0.26 \\
\hline Valerate & 0.9 & 0.8 & 0.8 & 0.1 & 0.58 & 0.87 \\
\hline Isovalerate & 1.2 & 1.2 & 1.0 & 0.1 & 0.04 & 0.03 \\
\hline Total & 105.0 & 103.7 & 105.3 & 6.7 & 0.97 & 0.82 \\
\hline
\end{tabular}

${ }^{1} \mathrm{CTL}=$ control; $\mathrm{VitE}=$ vitamin $\mathrm{E} ; \mathrm{APC}=$ alfalfa protein concentrate. 
Table 5. Effect of experimental diets on milk fat composition (g/100 g)

\begin{tabular}{|c|c|c|c|c|c|c|c|}
\hline \multirow[b]{2}{*}{ Fatty acid } & \multirow[b]{2}{*}{ Pretrial } & \multicolumn{3}{|c|}{ Treatment $^{1}$} & \multirow[b]{2}{*}{ SEM } & \multicolumn{2}{|c|}{$P$-value } \\
\hline & & CTL & VitE & $\mathrm{APC}$ & & APC vs. CTL & APC vs. VitE \\
\hline $4: 0$ & 2.366 & 2.376 & 2.286 & 2.183 & 0.150 & 0.39 & 0.64 \\
\hline $6: 0$ & 1.563 & 1.493 & 1.384 & 1.382 & 0.058 & 0.22 & 0.98 \\
\hline $8: 0$ & 0.941 & 0.935 & 0.853 & 0.873 & 0.024 & 0.10 & 0.58 \\
\hline 10:0 & 2.409 & 2.410 & 2.176 & 2.254 & 0.118 & 0.22 & 0.52 \\
\hline cis-9 10:1 & 0.250 & 0.211 & 0.193 & 0.206 & 0.008 & 0.44 & 0.08 \\
\hline $11: 0$ & 0.043 & 0.043 & 0.033 & 0.034 & 0.004 & 0.08 & 0.78 \\
\hline $12: 0$ & 2.987 & 2.874 & 2.569 & 2.651 & 0.184 & 0.23 & 0.64 \\
\hline cis-9 $12: 1$ & 0.090 & 0.081 & 0.071 & 0.077 & 0.006 & 0.45 & 0.37 \\
\hline iso $13: 0$ & 0.030 & 0.022 & 0.022 & 0.017 & 0.001 & 0.01 & 0.01 \\
\hline anteiso $13: 0$ & 0.015 & 0.017 & 0.014 & 0.011 & 0.001 & $<0.01$ & 0.17 \\
\hline $13: 0$ & 0.090 & 0.079 & 0.066 & 0.064 & 0.004 & $<0.01$ & 0.63 \\
\hline iso $14: 0$ & 0.125 & 0.101 & 0.092 & 0.085 & 0.004 & $<0.01$ & 0.13 \\
\hline $14: 0$ & 10.808 & 8.346 & 7.732 & 7.678 & 0.323 & 0.04 & 0.85 \\
\hline cis-9 14:1 & 0.949 & 0.571 & 0.542 & 0.548 & 0.032 & 0.35 & 0.80 \\
\hline cis-11 14:1 & 0.041 & 0.047 & 0.039 & 0.045 & 0.005 & 0.66 & 0.26 \\
\hline iso $15: 0$ & 0.260 & 0.251 & 0.220 & 0.187 & 0.012 & $<0.01$ & 0.05 \\
\hline anteiso $15: 0$ & 0.499 & 0.386 & 0.343 & 0.289 & 0.016 & $<0.01$ & $<0.01$ \\
\hline $15: 0$ & 1.126 & 0.949 & 0.843 & 0.902 & 0.025 & 0.16 & 0.10 \\
\hline iso $16: 0$ & 0.229 & 0.183 & 0.168 & 0.145 & 0.007 & $<0.01$ & 0.02 \\
\hline $16: 0$ & 30.446 & 20.434 & 19.637 & 19.213 & 1.057 & 0.25 & 0.68 \\
\hline trans-9 $16: 1$ & 0.065 & 0.049 & 0.054 & 0.050 & 0.005 & 0.98 & 0.60 \\
\hline iso $17: 0^{2}$ & 0.290 & 0.234 & 0.221 & 0.184 & 0.007 & $<0.01$ & $<0.01$ \\
\hline cis-9 16:1 & 1.321 & 0.712 & 0.669 & 0.675 & 0.086 & 0.52 & 0.92 \\
\hline anteiso $17: 0^{3}$ & 0.464 & 0.325 & 0.324 & 0.281 & 0.010 & $<0.01$ & 0.01 \\
\hline cis-11 16:1 & 0.024 & 0.019 & 0.016 & 0.017 & 0.001 & 0.41 & 0.67 \\
\hline cis-13 16:1 & 0.167 & 0.142 & 0.120 & 0.128 & 0.012 & 0.25 & 0.54 \\
\hline $17: 0$ & 0.534 & 0.459 & 0.434 & 0.452 & 0.010 & 0.61 & 0.24 \\
\hline cis-7 17:1 & 0.026 & 0.031 & 0.028 & 0.029 & 0.002 & 0.36 & 0.71 \\
\hline cis-8 $17: 1$ & 0.062 & 0.062 & 0.059 & 0.055 & 0.003 & 0.05 & 0.18 \\
\hline cis-9 17:1 & 0.212 & 0.139 & 0.141 & 0.146 & 0.007 & 0.46 & 0.61 \\
\hline iso 18:0 & 0.055 & 0.043 & 0.050 & 0.042 & 0.004 & 0.85 & 0.18 \\
\hline $18: 0$ & 7.723 & 7.023 & 7.273 & 7.014 & 0.313 & 0.98 & 0.41 \\
\hline trans-4 18:1 & 0.008 & 0.010 & 0.010 & 0.012 & 0.002 & 0.52 & 0.43 \\
\hline trans-5 18:1 & 0.007 & 0.009 & 0.008 & 0.009 & 0.001 & 0.75 & 0.49 \\
\hline trans-6-8 18:1 & 0.126 & 0.098 & 0.106 & 0.105 & 0.017 & 0.78 & 0.98 \\
\hline trans-9 18:1 & 0.123 & 0.094 & 0.099 & 0.102 & 0.012 & 0.62 & 0.83 \\
\hline trans-10 18:1 & 0.126 & 0.161 & 0.158 & 0.151 & 0.016 & 0.67 & 0.78 \\
\hline trans-11 18:1 & 1.635 & 1.431 & 1.524 & 1.568 & 0.103 & 0.37 & 0.77 \\
\hline trans-12 18:1 & 0.069 & 0.071 & 0.096 & 0.088 & 0.012 & 0.30 & 0.64 \\
\hline trans-13/14 18:1 & 0.011 & 0.054 & 0.104 & 0.081 & 0.019 & 0.34 & 0.42 \\
\hline trans-15 $18: 1$ & 0.589 & 0.471 & 0.619 & 0.655 & 0.129 & 0.34 & 0.85 \\
\hline trans-16 18:1 & 0.173 & 0.120 & 0.113 & 0.160 & 0.025 & 0.12 & 0.07 \\
\hline cis-6-8 $18: 1$ & 0.164 & 0.049 & 0.040 & 0.066 & 0.012 & 0.08 & 0.02 \\
\hline cis-9 $18: 1^{4}$ & 14.083 & 13.742 & 14.421 & 14.204 & 0.635 & 0.54 & 0.77 \\
\hline cis-11 18:1 & 0.847 & 0.718 & 0.865 & 0.989 & 0.131 & 0.18 & 0.52 \\
\hline cis-12 18:1 & 0.320 & 0.130 & 0.181 & 0.282 & 0.071 & 0.15 & 0.31 \\
\hline cis-13 18:1 & 0.152 & 0.035 & 0.041 & 0.113 & 0.042 & 0.16 & 0.19 \\
\hline cis-14 18:1 & 0.059 & 0.034 & 0.037 & 0.054 & 0.010 & 0.13 & 0.18 \\
\hline cis-15 18:1 & 0.069 & 0.030 & 0.033 & 0.056 & 0.013 & 0.10 & 0.14 \\
\hline cis-9,cis-12 18:2 & 1.072 & 3.737 & 3.854 & 4.123 & 0.160 & 0.06 & 0.16 \\
\hline cis-9,trans-11 $18: 2^{5}$ & 0.763 & 0.760 & 0.920 & 0.915 & 0.066 & 0.08 & 0.95 \\
\hline cis-9,trans-12 18:2 & 0.028 & 0.036 & 0.032 & 0.038 & 0.003 & 0.55 & 0.15 \\
\hline cis-9,trans-13 18:2 & 0.072 & 0.068 & 0.072 & 0.079 & 0.006 & 0.17 & 0.32 \\
\hline trans- 8, cis-12 $18: 2$ & 0.098 & 0.081 & 0.094 & 0.093 & 0.011 & 0.23 & 0.93 \\
\hline trans-8,cis-13 18:2 & 0.066 & 0.046 & 0.057 & 0.052 & 0.007 & 0.47 & 0.54 \\
\hline trans -9, trans $-12 \quad 18: 2$ & 0.024 & 0.010 & 0.009 & 0.017 & 0.004 & 0.16 & 0.13 \\
\hline trans -9, cis-12 $18: 2$ & 0.024 & 0.024 & 0.028 & 0.023 & 0.003 & 0.70 & 0.23 \\
\hline trans-10,cis-12 18:2 & 0.025 & 0.022 & 0.022 & 0.039 & 0.007 & 0.11 & 0.10 \\
\hline trans-11,cis-15 18:2 & 0.253 & 0.312 & 0.426 & 0.352 & 0.090 & 0.75 & 0.56 \\
\hline cis-9,trans-11,cis-15 18:3 & 0.041 & 0.532 & 0.638 & 0.591 & 0.059 & 0.43 & 0.53 \\
\hline cis-6,cis-9,cis-12 18:3 & 0.022 & 0.016 & 0.019 & 0.029 & 0.005 & 0.12 & 0.23 \\
\hline cis-9,cis-12,cis-15 18:3 & 0.399 & 13.576 & 14.420 & 14.828 & 0.754 & 0.26 & 0.71 \\
\hline cis-6,cis-9,cis-12,cis-15 18:4 & 0.011 & 0.021 & 0.019 & 0.019 & 0.002 & 0.54 & 0.92 \\
\hline 19:0 & 0.140 & 0.062 & 0.065 & 0.090 & 0.015 & 0.12 & 0.16 \\
\hline
\end{tabular}


Table 5 (Continued). Effect of experimental diets on milk fat composition (g/100 g)

\begin{tabular}{|c|c|c|c|c|c|c|c|}
\hline \multirow[b]{2}{*}{ Fatty acid } & \multirow[b]{2}{*}{ Pretrial } & \multicolumn{3}{|c|}{ Treatment $^{1}$} & \multirow[b]{2}{*}{ SEM } & \multicolumn{2}{|c|}{$P$-value } \\
\hline & & CTL & VitE & $\mathrm{APC}$ & & APC vs. CTL & APC vs. VitE \\
\hline cis-9 20:1 & 0.106 & 0.086 & 0.084 & 0.087 & 0.005 & 0.85 & 0.61 \\
\hline cis-11 20:1 & 0.032 & 0.035 & 0.032 & 0.037 & 0.004 & 0.72 & 0.41 \\
\hline cis-11,cis-14 20:2 & 0.021 & 0.032 & 0.032 & 0.033 & 0.002 & 0.87 & 0.81 \\
\hline cis-11,cis-14,cis-17 20:3 & 0.013 & 0.142 & 0.129 & 0.126 & 0.015 & 0.19 & 0.76 \\
\hline cis-5,cis-8,cis-11,cis-14,cis-17 20:5 & 0.093 & 0.268 & 0.240 & 0.212 & 0.027 & 0.13 & 0.41 \\
\hline $22: 0$ & 0.054 & 0.063 & 0.080 & 0.063 & 0.015 & 0.97 & 0.42 \\
\hline cis-13 22:1 & 0.010 & 0.008 & 0.009 & 0.008 & 0.001 & 0.79 & 0.94 \\
\hline cis-13,cis-16 22:2 & 0.046 & 0.066 & 0.049 & 0.048 & 0.007 & 0.13 & 0.92 \\
\hline cis-13,cis-16,cis-19 22:3 & 0.008 & 0.009 & 0.008 & 0.008 & 0.001 & 0.41 & 0.77 \\
\hline cis-7,cis-10,cis-13,cis-16 22:4 & 0.014 & 0.013 & 0.009 & 0.008 & 0.002 & 0.12 & 0.88 \\
\hline cis-4,cis-7,cis-10,cis-13,cis-16 22:5 & 0.010 & 0.015 & 0.011 & 0.011 & 0.002 & 0.12 & 0.90 \\
\hline
\end{tabular}

${ }^{1} \mathrm{CTL}=$ control; VitE $=$ vitamin $\mathrm{E} ; \mathrm{APC}=$ alfalfa protein concentrate.

${ }^{2}$ Coelution with minor concentration of trans-10 16:1.

${ }^{3}$ Coelution with minor concentration of cis-10 16:1.

${ }^{4}$ Coelution with minor concentration of cis-10 18:1.

${ }^{5}$ Coelution with minor concentration of trans-7, cis-9 18:2.

previously. Variation in ruminal branched-chain VFA can also indicate changes in the relative abundance of specific bacterial populations in the rumen due to a difference in rumen degradability of protein between APC and SBM or to variation in rumen metabolism due to an increase in vitamin E supplementation.

\section{Milk Fatty Acid Composition}

As a result of abomasal linseed oil infusion, milk fat concentrations of cis-9,cis-12 18:2 increased from $1.08 \pm 0.13$ to $3.90 \pm 0.40 \%$ (mean $\pm \mathrm{SD}$ ), whereas cis-9,cis-12,cis-15 18:3 increased from $0.40 \pm 0.04$ to $14.27 \pm 1.81 \%$ on average during the experimental period compared with the pretrial period (Table 5). The increase in milk PUFA was mostly at the expense of 14:0 (from $10.81 \pm 0.89$ to $7.92 \pm 0.87 \%$, respectively) and 16:0 (from $30.45 \pm 2.88$ to $19.76 \pm 2.54 \%$, respectively). When comparing dietary treatments, the proportion of cis-9,cis-12 18:2 tended to be higher when cows were fed APC compared with CTL. Dang Van et al. (2011) reported decreased ruminal biohydrogenation of cis-9,cis-12 18:2 and cis-9,cis-12,cis-15 18:3 for APC compared with extruded linseed and extruded rapeseed in vitro. Moreover, Hurtaud et al. (2013) observed a greater efficiency of transfer from diet to milk for cis9,cis-12 18:2 and cis-9,cis-12,cis-15 18:3 when comparing APC with extruded linseed. However, under the conditions of the current experiment, no difference was observed in milk concentration of cis-9,cis-12, cis- 15 18:3 among treatments. Indeed, because APC was a minor source of cis-9, cis-12, cis-15 18:3, a potential effect of protection from APC would have been overshadowed by the amount of this fatty acid provided by the continuous abomasal infusion of linseed oil.

Compared with the pretrial period, and regardless of dietary treatment, abomasal linseed oil infusion increased milk fat concentrations of cis-9,trans-11,cis- 15 $18: 3$ from $0.041 \pm 0.005$ to $0.587 \pm 0.138 \%$, and trans11, cis- 15 18:2 from $0.253 \pm 0.020$ to $0.363 \pm 0.213 \%$ (Table 5). These isomers have been identified as the most common intermediates produced in the first steps of the biohydrogenation process of cis-9,cis-12, cis- 15 18:3 (Saliba et al., 2014). The increased concentrations of these isomers in milk fat may suggest some degree of residual biohydrogenation activity in ruminal fluid flowing to the abomasum, allowing the first steps of the process to be performed.

Feeding the APC diet reduced milk fat concentrations of most of the branched-chain fatty acids (BCFA) compared with CTL and VitE (Table 5), except for iso 18:0, for which no significant difference was observed. It has been shown that branched-chain VFA can serve as primers to microbial fatty acid synthetase and lead to de novo synthesis of BCFA in the rumen (Vlaeminck et al., 2006). Lower milk BCFA is therefore in line 
FAUTEUX ET AL.

Table 6. Effect of experimental diets on plasma concentrations of carotenoids

\begin{tabular}{|c|c|c|c|c|c|c|}
\hline \multirow[b]{2}{*}{ Carotenoid } & \multicolumn{3}{|c|}{ Treatment $^{1}$} & \multirow[b]{2}{*}{ SEM } & \multicolumn{2}{|c|}{$P$-value } \\
\hline & CTL & VitE & $\mathrm{APC}$ & & APC vs. CTL & APC vs. VitE \\
\hline$\alpha$-Carotenes, ng/mL & 58 & 69 & 87 & 13 & 0.03 & 0.11 \\
\hline$\beta$-Carotenes, $\mu \mathrm{g} / \mathrm{mL}$ & 16 & 17 & 17 & 1 & 0.12 & 0.36 \\
\hline$\beta$-Cryptoxanthin, ng/mL & 214 & 221 & 247 & 21 & 0.06 & 0.09 \\
\hline Lutein, $\mathrm{ng} / \mathrm{mL}$ & 113 & 117 & 159 & 15 & $<0.01$ & $<0.01$ \\
\hline Lycopene, ng/mL & 337 & 419 & 375 & 41 & 0.32 & 0.21 \\
\hline Zeaxanthin, ng/mL & 52 & 50 & 47 & 5 & 0.27 & 0.38 \\
\hline
\end{tabular}

${ }^{1} \mathrm{CTL}=$ control VitE $=$ vitamin $\mathrm{E} ; \mathrm{APC}=$ alfalfa protein concentrate.

with the decrease in branched-chain VFA in the rumen observed with APC. Milk BCFA could provide a qualitative description of the proportions of different classes of microbes leaving the rumen (Dewhurst et al., 2000). In this regard, Vlaeminck et al. (2006) reported a negative correlation between milk anteiso $17: 0$ and rumen $\mathrm{CP}$ availability. In agreement with that study, feeding APC, as a potentially less degradable protein source, decreased concentration of anteiso 17:0 in milk fat compared with CTL and VitE (Table 5). Similarly, a decrease in milk iso 17:0 content was reported by Hurtaud et al. (2013) when feeding APC compared with extruded linseed, even when the supply of rumendegradable protein was adjusted between treatments by using untreated and formaldehyde-treated SBM.

\section{Transfer of Carotenoids}

Six carotenoids were identified in plasma (Table 6). Among them, lutein was increased in cows fed APC compared with CTL and VitE. Concentrations of $\alpha$-carotene and $\beta$-cryptoxanthin (tendency) were also higher in plasma from cows fed APC compared with CTL, and tended to be higher compared with VitE. In contrast, we detected no effect of treatments on $\beta$-carotene, lycopene, or zeaxanthin.
In a previous experiment, Calderón et al. (2007b) observed a significant increase in $\beta$-carotene, lutein, and zeaxanthin in plasma from cows receiving increasing amounts of APC supplement (from 0 to $2.7 \mathrm{~kg} / \mathrm{d}$, compared with $1.6 \mathrm{~kg} / \mathrm{d}$ in the present feeding trial). Among these 3 carotenoids, in the current study, only lutein was significantly increased in plasma from cows receiving the APC diet compared with CTL and VitE, and the increase was of similar magnitude (approximately $40 \%$ ) as that observed in the study from Calderón et al. (2007b). In the latter study, feeding $2.7 \mathrm{~kg} / \mathrm{d}$ of APC to dairy cows increased zeaxanthin by $80 \%$ and $\beta$-carotene by 66 to $189 \%$.

The discrepancy between studies could originate from the continuous abomasal infusion of linseed oil $(450 \mathrm{~g} / \mathrm{d})$ performed in the current trial, in contrast to the work from Calderón et al. (2007b), in which no supplemental fat was provided. Rumen infusions of dietary fatty acids affect the fatty acid composition of plasma and lipoprotein fractions in dairy cows, and the effects are reported to be consistent with the fatty acid composition of the dietary supplement infused (VargasBello-Pérez and Garnsworthy, 2010). Therefore, it is expected that infusion of linseed oil might have increased the content of PUFA in plasma lipoproteins and concurrently increased their oxidizability (Nestel

Table 7. Effect of experimental diets on carotenoid and vitamin E content of milk and milk fat

\begin{tabular}{|c|c|c|c|c|c|c|}
\hline \multirow[b]{2}{*}{ Item } & \multicolumn{3}{|c|}{ Treatment $^{1}$} & \multirow[b]{2}{*}{ SEM } & \multicolumn{2}{|c|}{$P$-value } \\
\hline & CTL & VitE & $\mathrm{APC}$ & & APC vs. CTI & PC vs. VitE \\
\hline \multicolumn{7}{|l|}{$\overline{\text { Vitamin E }}$} \\
\hline$\mu \mathrm{g} / \mathrm{mL}$ of milk & 0.80 & 1.96 & 1.50 & 0.19 & 0.03 & 0.11 \\
\hline$\mu \mathrm{g} / \mathrm{g}$ of milk fat & 19.0 & 44.9 & 34.5 & 4.19 & 0.03 & 0.14 \\
\hline \multicolumn{7}{|l|}{$\beta$-Carotenes } \\
\hline $\mathrm{ng} / \mathrm{mL}$ of milk & 72.5 & 72.5 & 75.9 & 17.7 & 0.82 & 0.81 \\
\hline $\mathrm{ng} / \mathrm{g}$ of milk fat & 1,721 & 1,652 & 1,780 & 398 & 0.85 & 0.67 \\
\hline \multicolumn{7}{|l|}{ Lutein } \\
\hline $\mathrm{ng} / \mathrm{mL}$ of milk & 8.68 & 8.24 & 10.71 & 0.80 & 0.01 & 0.01 \\
\hline $\mathrm{ng} / \mathrm{g}$ of milk fat & 204 & 190 & 252 & 16.3 & $<0.01$ & $<0.01$ \\
\hline \multicolumn{7}{|l|}{ Zeaxanthin } \\
\hline $\mathrm{ng} / \mathrm{mL}$ of milk & 6.09 & 6.25 & 6.38 & 0.35 & 0.38 & 0.69 \\
\hline $\mathrm{ng} / \mathrm{g}$ of milk fat & 142 & 144 & 151 & 7.13 & 0.21 & 0.32 \\
\hline
\end{tabular}

${ }^{1} \mathrm{CTL}=$ control; VitE $=$ vitamin $\mathrm{E} ; \mathrm{APC}=$ alfalfa protein concentrate. 
Table 8. Effect of experimental diets on color index of butter

\begin{tabular}{|c|c|c|c|c|c|c|}
\hline \multirow[b]{2}{*}{ Color index ${ }^{1}$} & \multicolumn{3}{|c|}{ Treatment $^{2}$} & \multirow[b]{2}{*}{ SEM } & \multicolumn{2}{|c|}{$P$-value } \\
\hline & CTL & VitE & $\mathrm{APC}$ & & APC vs. CTL & APC vs. VitE \\
\hline$\overline{\mathrm{L}^{*}}$ & 87.6 & 87.4 & 86.7 & 0.4 & 0.33 & 0.69 \\
\hline$a^{*}$ & -1.6 & -1.7 & -1.7 & 0.1 & 0.47 & 0.89 \\
\hline $\mathrm{b}^{*}$ & 29.4 & 28.0 & 30.8 & 1.4 & 0.14 & 0.04 \\
\hline
\end{tabular}

et al., 1997). Oxidation of lipoproteins is a free radical process in which total PUFA contained in the lipoproteins are degraded by lipid peroxidation to a great variety of aldehydes and other products (Esterbauer et al., 1991). Carotenoids circulate in bovine plasma in the different lipoproteins, but predominantly in highdensity lipoproteins (Schweigert et al., 1987). Carotenoids efficiently quench single oxygen (Sundquist et al., 1994) and can therefore protect lipoproteins against lipid peroxidation (Dugas et al., 1998). The interaction of carotenoids with radicals results in the formation of ketones and aldehydes of different chain lengths and epoxides (Sies and Stahl, 1995), and therefore decreases carotenoid concentrations in plasma. Considering the high amounts of PUFA infused in the current study, it is possible that part of the absorbed carotenoids were used to protect lipoproteins from lipid peroxidation, and that carotenoids were depleted during the scavenging of free radicals, which would explain the low plasma carotenoid concentrations observed, when compared with previous work from Calderón et al. (2007b).

The HPLC method used in the current study technically allowed us to determine neoxanthin and violaxanthin contents. Nevertheless, these xanthophylls, which were found in high concentrations in the APC supplement, were not detected in plasma or milk samples (Tables 6 and 7). Nozière et al. (2006a) suggested that the absence of violaxanthin in bovine plasma could be due to microbial degradation in the rumen (Cardinault et al., 2004), to conversion into zeaxanthin (van den Berg et al., 2000), or to rapid transfer to tissues from intestinal chylomicrons. The results of the current study support a similar fate for neoxanthin.
The colors of carotenoids range from pale yellow to deep red, xanthophylls, carotenes ( $\alpha$ - and $\beta-)$, and lycopene being associated with yellow, orange, and red coloring, respectively. For this reason, previous works have considered the color index as a convenient method to estimate carotenoid levels in plasma from dairy cows (Nozière et al., 2006b; Calderón et al., 2007a). Consistent with previous results, in the present work, individual carotenoids were all statistically and positively correlated with color index $\left(\mathrm{R}^{2}=26\right.$ to $78 \%$; data not shown) and total plasma carotenoid concentration explained $76 \%$ of the color index variation (Figure 1). A marked interindividual variability was observed for plasma carotenoid concentrations and color index. Such variability was observed in previous work looking at carotenoids in plasma from sheep (Karijord, 1978; Yang et al., 1992; Prache et al., 2003) and plasma color index in dairy cows (Calderón et al., 2007a,b). Important interindividual variation in plasma response to dietary carotenoid has also been observed in humans, with some subjects exhibiting a large increase in plasma concentration and others exhibiting very little change in response to an identical dose consumed (Micozzi et al., 1992). Part of this variability could be due to differences in rates of conversion of $\beta$-carotene into vitamin A at the intestinal level (Parker, 1996). However, other aspects of absorption and metabolic polymorphism are likely to exist (Rock, 1997).

Carotenoids are transferred from the diet to milk fat, and thus also contribute to the yellow coloration of butter (Nozière et al., 2006a). Previous work reported significant relationships between $\beta$-carotene concentrations and color of milk (Calderón et al. 2007a). In the

Table 9. Effect of experimental diets on redox potential, dissolved oxygen, and conjugated diene hydroperoxides in milk

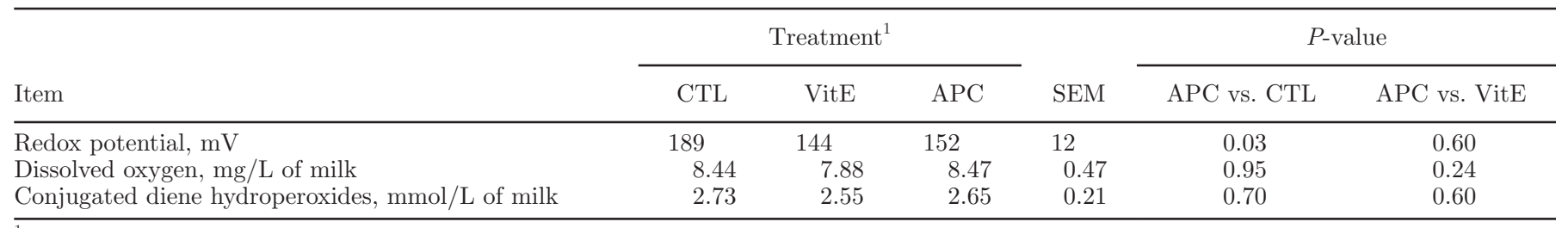

${ }^{1} \mathrm{CTL}=$ control; VitE $=$ vitamin $\mathrm{E} ; \mathrm{APC}=$ alfalfa protein concentrate. 


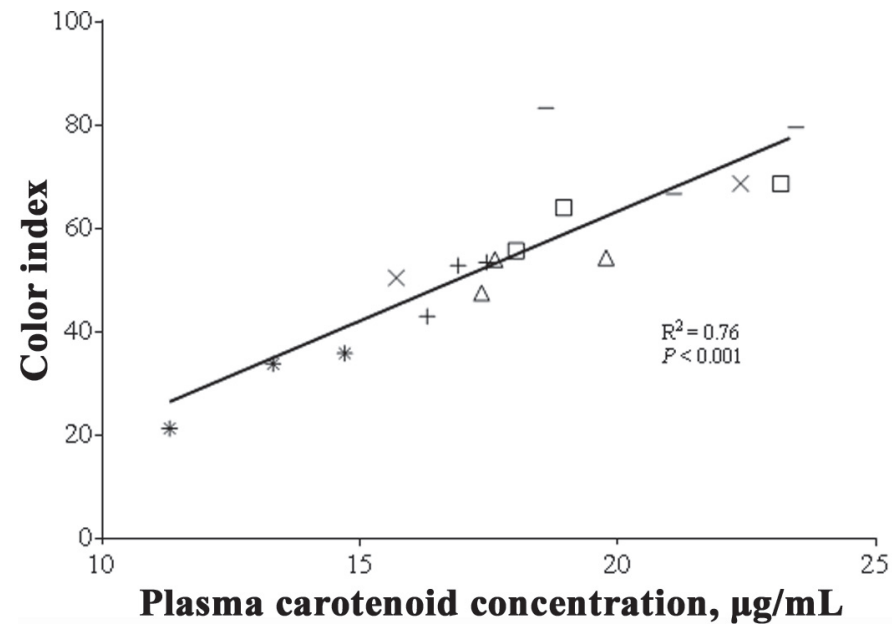

Figure 1. Relationship between plasma color index and carotenoid concentration. Different symbols represent values of individual cows when receiving the 3 dietary treatments.

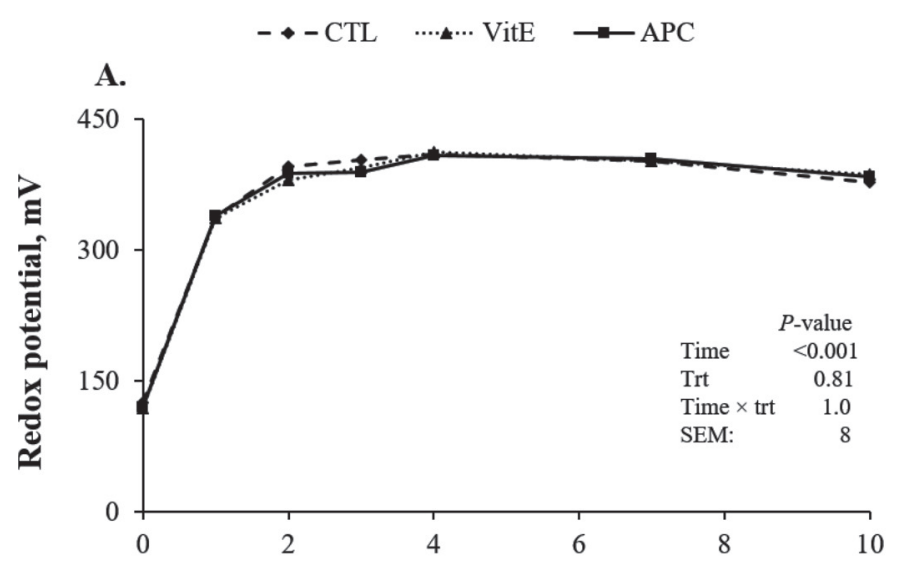

B.

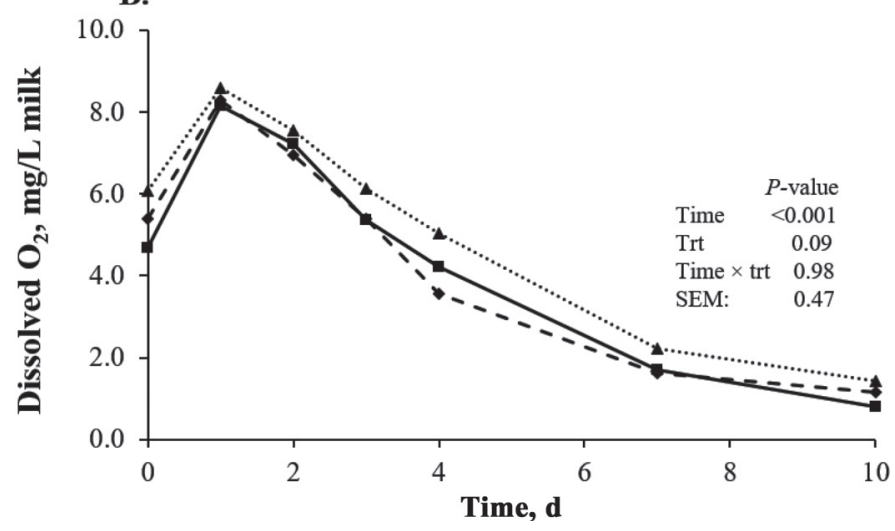

Figure 2. Effect of time of storage under light exposure on redox potential (A) and dissolved oxygen (B) in homogenized milk from cows fed control (CTL), supplemental vitamin E (VitE), or alfalfa protein concentrate (APC) diets. Pooled SEM: panel $\mathrm{A}=8 \mathrm{mV}$; panel $\mathrm{B}=$ $0.54 \mathrm{mg} / \mathrm{mL}$. No treatment (trt) differences were detected at any time point.

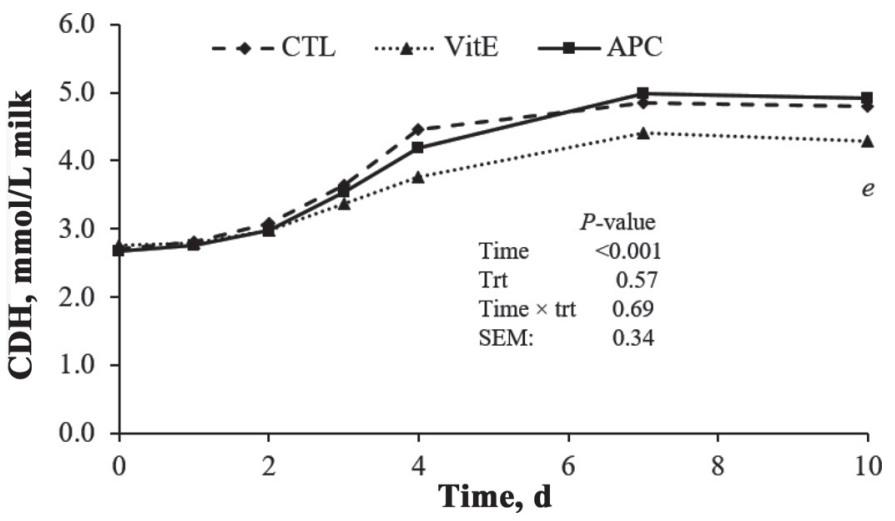

Figure 3. Effect of time of storage under light exposure on conjugated diene hydroperoxides $(\mathrm{CDH})$ in milk from cows fed control (CTL), supplemental vitamin E (VitE), or alfalfa protein concentrate (APC) diets. Pooled SEM $=0.34 \mathrm{mmol} / \mathrm{L}$. Preplanned contrasts revealed a tendency for a difference between VitE and $\mathrm{APC}(e=P<$ $0.15)$. trt $=$ treatment.

current study, only $\beta$-carotene, lutein, and zeaxanthin were detected in milk (Table 7). Feeding APC had no effect on milk concentrations of $\beta$-carotene and zeaxanthin, but increased lutein relative to both CTL and VitE by more than $23 \%$. Interestingly, butter obtained from cows fed APC diet had a higher yellow coloration, indicated by a higher $b^{*}$ value, compared with CTL (tendency) and VitE diets (Table 8).

\section{Lipid Oxidation}

The oxidation-reduction ability of a molecule and its prevalent form (oxidized or reduced) in the system can be obtained by measuring the redox potential value of milk (Nicoli et al., 2004). Previous studies reported a positive correlation between oxidized flavor and milk redox potential (Matumoto-Pintro et al., 2011). Under the conditions of the current experiment, fresh nonhomogenized milk from cows fed the APC diet had a lower redox potential compared with CTL, whereas no difference was observed between APC and VitE (Table 9 ). However, we detected no effect of treatment and no time $\times$ treatment interaction when milk samples were homogenized and submitted to light-induced oxidation during storage (Figure 2A).

Feeding APC to lactating dairy cows did not affect the dissolved oxygen concentration in fresh nonhomogenized milk, which averaged $8.1 \pm 1.5 \mathrm{mg} / \mathrm{L}$ of milk among treatments (Table 9). During storage, dissolved oxygen is consumed by fat oxidation reactions (Matumoto-Pintro et al., 2011). Therefore, a reduction in milk dissolved oxygen concentration is associated with an increase in milk oxidation (Noll and Supplee, 1941). Dissolved oxygen concentration in the homogenized milk samples during storage under fluorescent-light 
Table 10. Effect of experimental diets on concentrations of volatile lipid oxidation products in fresh milk

\begin{tabular}{|c|c|c|c|c|c|c|}
\hline \multirow[b]{2}{*}{ Item } & \multicolumn{3}{|c|}{ Treatment $^{1}$} & \multirow[b]{2}{*}{ SEM } & \multicolumn{2}{|c|}{$P$-value } \\
\hline & CTL & VitE & $\mathrm{APC}$ & & APC vs. CTL & APC vs. VitE \\
\hline Propanal, $\mu \mathrm{g} / \mathrm{kg}$ & 281 & 185 & 203 & 39 & 0.07 & 0.61 \\
\hline Hexanal, $\mu \mathrm{g} / \mathrm{kg}$ & 68.9 & 27.4 & 45.9 & 12.3 & 0.03 & 0.05 \\
\hline Hept-cis-4-enal, $\mu \mathrm{g} / \mathrm{kg}$ & 2.47 & 2.08 & 2.19 & 0.14 & 0.15 & 0.53 \\
\hline 1-Octen-3-one, $\mu \mathrm{g} / \mathrm{kg}$ & 2.80 & 1.71 & 2.03 & 0.05 & 0.05 & 0.35 \\
\hline
\end{tabular}

${ }^{1} \mathrm{CTL}=$ control; $\mathrm{VitE}=$ vitamin $\mathrm{E} ; \mathrm{APC}=$ alfalfa protein concentrate.

exposure decreased over time, and its time course was similar for all treatments (Figure 2B).

As mentioned previously, lipid oxidation is characterized by the reaction between peroxyl radicals and oxygen, and leads to synthesis of conjugated diene hydroperoxides. The autoxidation of linoleic and linolenic acids produces conjugated products (Choe and Min, 2006), which can be measured by spectrophotometric absorption of UV light at $232 \mathrm{~nm}$ (Boroski et al., 2012).
In the current study, feeding APC to lactating dairy cows did not affect conjugated diene hydroperoxide concentrations in fresh nonhomogenized milk, which averaged $2.7 \pm 0.5 \mathrm{mmol} / \mathrm{L}$, regardless of dietary treatment (Table 9). Under light-exposure conditions, the duration of storage had a significant effect on milk conjugated diene hydroperoxide concentrations, but the temporal pattern was similar among treatments (Figure 3).

$$
\rightarrow-\mathrm{CTL} \quad \cdots \ldots \text { VItE } \rightarrow-\mathrm{APC}
$$

A.

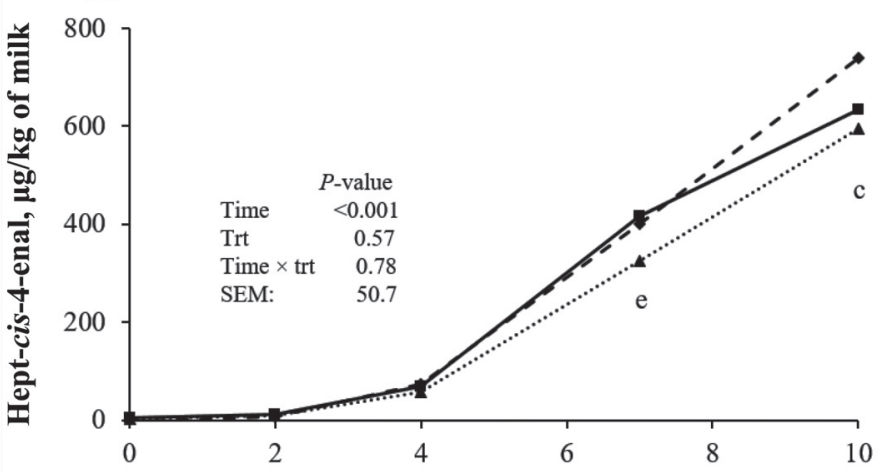

C.

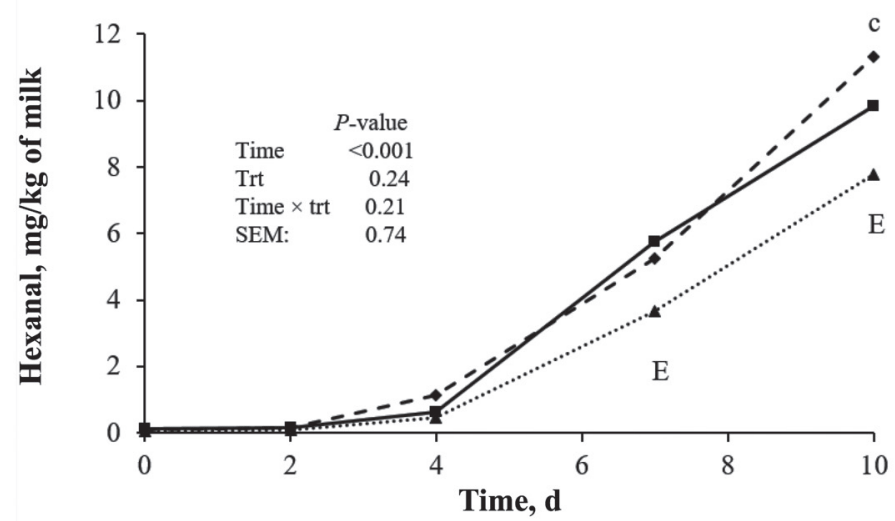

B.

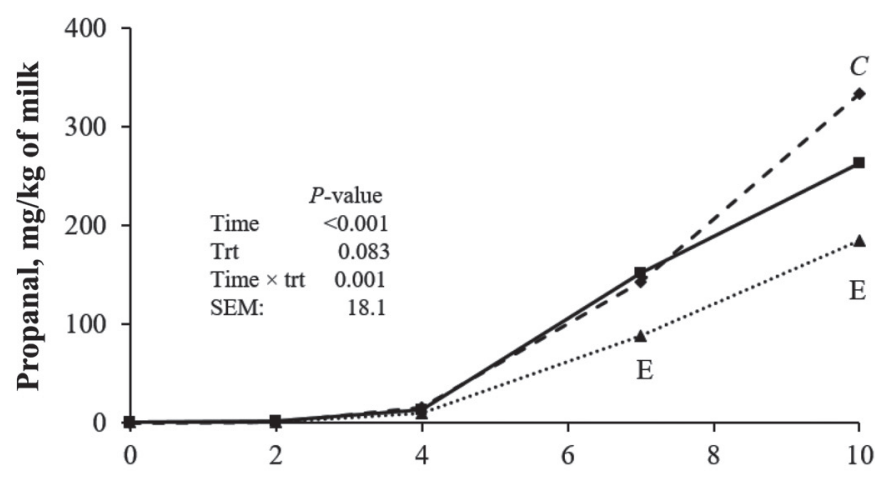

D.

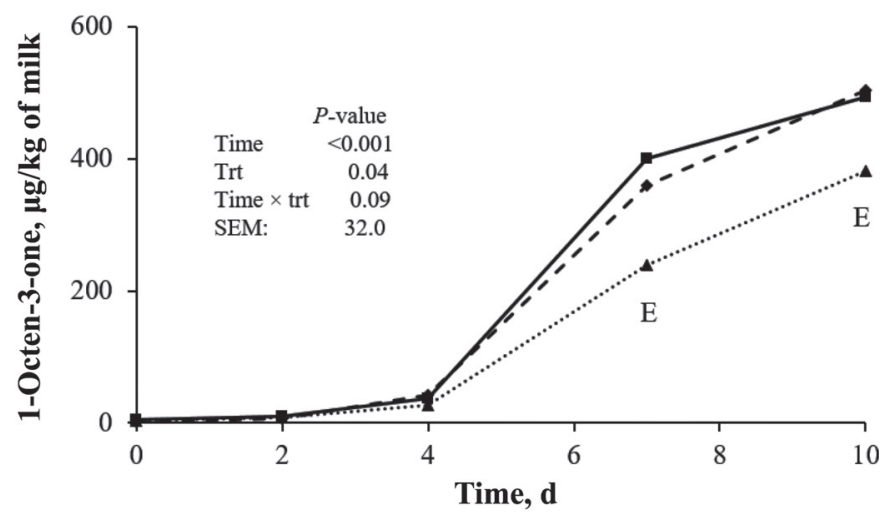

Figure 4. Effect of time on the concentrations of volatile lipid oxidation products hept-cis-4-enal (A), propanal (B), hexanal (C), and 1-octen-3-one (D) in homogenized milk from cows fed control (CTL), supplemental vitamin E (VitE), or alfalfa protein concentrate (APC) diets. Preplanned contrasts revealed significant differences or a tendency for differences between CTL and APC $(C=P<0.05$ and $\mathrm{c}=P<0.15$, respectively), and between VitE and $\mathrm{APC}(\mathrm{E}=P<0.05$ and $\mathrm{e}=P<0.15$, respectively). trt $=$ treatment. 
Propanal and hept-cis-4-enal are 2 aldehydes that originate from linolenate hydroperoxides, whereas hexanal originates from linoleate hydroperoxides (Bendall, 2001; Frankel, 2005). From the ketone family, 1-octen-3-one is another aromatic molecule derived from cis-9,cis-12 18:2 oxidation (Ullrich and Grosch, 1988). All these volatile compounds are characterized by their intense aroma and flavor effects at very low threshold values (Labuza and Dugan, 1971; Mestdagh et al., 2005). In the current trial, 1-octen-3-one was detected with less intensity in fresh nonhomogenized milk from cows fed APC compared with CTL (Table 10), whereas no difference was observed between APC and VitE. A similar tendency was observed for propanal and hept-cis-4-enal. Hexanal concentration in fresh nonhomogenized milk from cows fed APC was greater than in VitE but lower than in CTL.

During 10-d storage under light exposure of homogenized milk samples, concentrations of these lipid oxidation derivatives were increased in all treatments and more extensively after $4 \mathrm{~d}$ (quadratic effect of time: $P<0.01$; Figure 4). Despite a clear effect of time, no effect of treatment or time $\times$ treatment interaction was observed for hept-cis-4-enal concentrations in milk. Propanal and hexanal concentrations were also increased over time for all treatments. However, at d 7 and 10 of storage, milk from cows receiving the VitE diet showed lower concentrations of these 2 volatile compounds compared with APC, whereas no differences were detected between milk from cows fed APC or CTL at any time point. Concentrations of 1-octen3 -one were affected by both time and treatment, and a tendency for a time $\times$ treatment interaction was observed. More precisely, after 7 and $10 \mathrm{~d}$ of storage, milk from cows receiving VitE had lower concentrations of 1-octen-3-one compared with APC, whereas milk from cows fed CTL or APC was not different.

Under the conditions of the present experiment, increasing milk fat content of PUFA, specifically cis-9,cis-12 18:2 and cis-9,cis-12,cis-15 18:3, clearly impaired the oxidative stability of milk, regardless of dietary treatments. Apart from some effects for VitE, effects of treatment observed on oxidation of fresh milk were not present when looking at oxidative stability during storage. Increased $\alpha$-tocopherol levels in milk have previously been associated with a decrease in oxidation flavor in milk (Charmley and Nicholson, 1993). However, when supplementing cow diets with $\alpha$-tocopherol and oilseeds, Focant et al. (1998) observed an increase in milk fat oxidation, despite an increase in $\alpha$-tocopherol levels in milk. They attributed this decline in oxidative stability to the increase in PUFA (especially cis-9, cis12,cis-15 18:3) in milk as the result of a high oilseed diet. Accordingly, Havemose et al. (2006) demonstrated that the concentration of cis-9,cis-12,cis-15 18:3 in milk fat was very important for autoxidation susceptibility and was directly influenced by the type of feed. To our knowledge, this is the first time that oxidative stability of milk with such high cis-9,cis-12,cis-15 18:3 concentrations obtained by supplementing cow diets with abomasally infused linseed oil has been evaluated. The milk fat globule membrane is considered a major site of autoxidation (Lindmark-Månsson and Åkesson, 2000). Additionally, Smith et al. (1963) reported that an increase in susceptibility of milk to oxidation appears to be more dependent on an increase of PUFA content of the phospholipids rather than the milk fat. Therefore, it is possible that, in the current study, an increase in milk fat content in PUFA by abomasal infusion of 450 $\mathrm{g} / \mathrm{d}$ of linseed oil allowed PUFA enrichment of not only triacylglycerols but also phospholipids. This modification in milk fat composition might have considerably increased the susceptibility of milk to autoxidation. In spite of its compromised oxidative stability, fresh milk from cows fed APC presented decreased concentrations of lipid oxidation products (propanal, hexanal, and 1-octen-3-one) compared with CTL, confirming a potential antioxidant protection from APC.

\section{CONCLUSIONS}

Abomasal infusion of linseed oil to lactating dairy cows significantly increased cis-9,cis-12 18:2 and cis9 , cis-12,cis-15 18:3 concentrations in milk fat and clearly challenged the oxidative stability of milk, as indicated by a marked increase in all oxidation products measured during $10 \mathrm{~d}$ of storage under light exposure, regardless of dietary treatments. The positive effect on the oxidative stability of fresh milk allowed us to confirm the potential of supplementing cow diets with APC as both a preharvest technology to increase natural antioxidant levels in milk to limit oxidation and as a source of dietary protein that improves $\mathrm{N}$ utilization efficiency. However, further research is needed to explore the extent of antioxidant protection from carotenoids that could be expected in milk enriched in cis-9, cis12, cis-15 18:3 but under moderate enrichment levels.

\section{ACKNOWLEDGMENTS}

This experiment was funded through the Industrial Research Chair program of the Natural Sciences and Engineering Research Council of Canada (Ottawa, ON, Canada), with industry contributions from Dairy Farmers of Canada (Ottawa, ON, Canada), Novalait Inc. (Québec, QC, Canada), Valacta (Sainte-Anne-deBellevue, QC, Canada), Les Producteurs de Lait du Québec (Longueuil, QC, Canada), Centre de Recherche 
en Sciences Animales de Deschambault (Deschambault, QC, Canada), and Ministère de l'Agriculture, des Pêcheries et de l'Alimentation du Québec (Québec, QC, Canada). Appreciation is extended to Didier Coulmier (Désialis, Châlons-en-Champagne, France) for providing Extraluz, to Raymond Lamoureux (9012-6582 Québec Inc., La Prairie, QC, Canada) for providing linseed oil, and to Philippe Rioux (Université Laval, Québec, QC, Canada) for technical assistance.

\section{REFERENCES}

AOAC International. 2005. Official Methods of Analysis. 18th ed. AOAC International, Arlington, VA.

Barrefors, P., K. Granelli, L.-A. Appelqvist, and L. Bjoerck. 1995. Chemical characterization of raw milk samples with and without oxidative off-flavor. J. Dairy Sci. 78:2691-2699. http://dx.doi. org/10.3168/jds.S0022-0302(95)76900-4.

Bendall, J. G. 2001. Aroma compounds of fresh milk from New Zealand cows fed different diets. J. Agric. Food Chem. 49:4825-4832. http://dx.doi.org/10.1021/if010334n.

Boivin, M., R. Gervais, and P. Y. Chouinard. 2013. Effect of grain and forage fractions of corn silage on milk production and composition in dairy cows. Animal 7:245-254. http://dx.doi.org/10.1017/ S1751731112001486.

Boroski, M., H. J. Giroux, H. Sabik, H. V. Petit, J. V. Visentainer, P. T. Matumoto-Pintro, and M. Britten. 2012. Use of oregano extract and oregano essential oil as antioxidants in functional dairy beverage formulations. LWT Food Sci. Technol. (Campinas.) 47:167174. http://dx.doi.org/10.1016/j.lwt.2011.12.018.

Calderón, F., B. Chauveau-Duriot, B. Martin, B. Graulet, M. Doreau, and P. Nozière. 2007a. Variations in carotenoids, vitamins A and $\mathrm{E}$, and color in cow's plasma and milk during late pregnancy and the first three months of lactation. J. Dairy Sci. 90:2335-2346. http://dx.doi.org/10.3168/jds.2006-630.

Calderón, F., B. Chauveau-Duriot, P. Pradel, B. Martin, B. Graulet, M. Doreau, and P. Nozière. 2007b. Variations in carotenoids, vitamins A and E, and color in cow's plasma and milk following a shift from hay diet to diets containing increasing levels of carotenoids and vitamin E. J. Dairy Sci. 90:5651-5664. http://dx.doi. org/10.3168/jds.2007-0264.

Canadian Council on Animal Care. 1993. Guidelines to the care and use of experimental animals, vol. 1, 2nd edition. CCAC, Ottawa, ON, Canada.

Cardinault, N., M. Doreau, and P. Nozière. 2004. Fate of carotenoids in the rumen. Renc. Rech. Rumin. 11:82.

Charmley, E., and J. W. G. Nicholson. 1993. Injectable $\alpha$-tocopherol for control of oxidized flavour in milk from dairy cows. Can. J. Anim. Sci. 73:381-392. http://dx.doi.org/10.4141/cjas93-040.

Choe, E., and D. B. Min. 2006. Mechanisms and factors for edible oil oxidation. Compr. Rev. Food Sci. Food Saf. 5:169-186. http:// dx.doi.org/10.1111/j.1541-4337.2006.00009.x.

Côrtes, C., R. Kazama, D. da Silva-Kazama, C. Benchaar, L. M. Zeoula, G. T. D. Santos, and H. V. Petit. 2011. Digestion, milk production and milk fatty acid profile of dairy cows fed flax hulls and infused with flax oil in the abomasum. J. Dairy Res. 78:293-300. http://dx.doi.org/10.1017/S0022029911000446.

Dang Van, Q. C., L. Bejarano, E. Mignolet, D. Coulmier, E. Froidmont, Y. Larondelle, and M. Focant. 2011. Effectiveness of extruded rapeseed associated with an alfalfa protein concentrate in enhancing the bovine milk fatty acid composition. J. Dairy Sci. 94:4005-4015. http://dx.doi.org/10.3168/jds.2011-4204.

Dewhurst, R. J., D. R. Davies, and R. J. Merry. 2000. Review article: Microbial protein supply from the rumen. Anim. Feed Sci. Technol. 85:1-21. http://dx.doi.org/10.1016/S0377-8401(00)00139-5.

Dugas, T. R., D. W. Morel, and E. H. Harrison. 1998. Impact of LDL carotenoid and $a$-tocopherol content on LDL oxidation by endothelial cells in culture. J. Lipid Res. 39:999-1007.
Esterbauer, H., M. Dieber-Rotheneder, G. Striegl, and G. Waeg. 1991. Role of vitamin $\mathrm{E}$ in preventing the oxidation of low-density lipoprotein. Am. J. Clin. Nutr. 53(Suppl.):314S-321S.

Flock, M. R., W. S. Harris, and P. M. Kris-Etherton. 2013. Long-chain omega-3 fatty acids: Time to establish a dietary reference intake. Nutr. Rev. 71:692-707. http://dx.doi.org/10.1111/nure.12071.

Focant, M., E. Mignolet, M. Marique, F. Clabots, T. Breyne, D. Dalemans, and Y. Larondelle. 1998. The effect of vitamin E supplementation of cow diets containing rapeseed and linseed on the prevention of milk fat oxidation. J. Dairy Sci. 81:1095-1101. http:// dx.doi.org/10.3168/jds.S0022-0302(98)75671-1.

Frankel, E. N. 2005. Lipid Oxidation. 2nd ed. The Oily Press, Bridgwater, UK.

Gaines, W. L. 1928. The energy basis of measuring milk yield in dairy cows. Tech. Bull. No. 308. Agric. Exp. Sta., Champaign, IL.

Gaweł, E., and M. Grzelak. 2012. The effect of a protein-xanthophyll concentrate from alfalfa (phytobiotic) on animal productionA current review. Ann. Anim. Sci. 12:281-289. http://dx.doi. org/10.2478/v10220-012-0023-5.

Giroux, H. J., J. Bédard St-Amant, P. Fustier, J.-M. Chapuzet, and M. Britten. 2008. Effect of electroreduction and heat treatments on oxidative degradation of a dairy beverage enriched with polyunsaturated fatty acids. Food Res. Int. 41:145-153. http://dx.doi. org/10.1016/j.foodres.2007.10.008.

Gressley, T. F., S. M. Reynal, J. J. Olmos Colmenero, G. A. Broderick, and L. E. Armentano. 2006. Development of a tool to insert abomasal infusion lines into dairy cows. J. Dairy Sci. 89:3965-3967. http://dx.doi.org/10.3168/jds.S0022-0302(06)72438-9.

Haratifar, S., L. Bazinet, N. Manoury, M. Britten, and P. Angers. 2011. Impact of redox potential modification and storage conditions on the oxidation reaction prevention in dairy emulsion. Dairy Sci. Technol. 91:541-554. http://dx.doi.org/10.1007/s13594-0110025-6.

Havemose, M. S., M. R. Weisbjerg, W. L. P. Bredie, H. D. Poulsen, and J. H. Nielsen. 2006. Oxidative stability of milk influenced by fatty acids, antioxidants, and copper derived from feed. J. Dairy Sci. 89:1970-1980. http://dx.doi.org/10.3168/jds.S00220302(06)72264-0.

Hurtaud, C., G. Chesneau, D. Coulmier, and J. L. Peyraud. 2013. Effects of extruded linseed or alfalfa protein concentrate in interaction with two levels of concentrates on milk production and composition in dairy cows. Livest. Sci. 158:64-73. http://dx.doi. org/10.1016/j.livsci.2013.10.002.

Jenkins, T. C. 2010. Technical note: Common analytical errors yielding inaccurate results during analysis of fatty acids in feed and digesta samples. J. Dairy Sci. 93:1170-1174. http://dx.doi.org/10.3168/ jds.2009-2509

Karijord, O. 1978. Correlation between the content of carotenoids in depot fat and in plasma of sheep. Acta Agric. Scand. 28:355-359. http://dx.doi.org/10.1080/00015127809435192.

Kay, J. K., J. R. Roche, E. S. Kolver, N. A. Thomson, and L. H. Baumgard. 2005. A comparison between feeding systems (pasture and TMR) and the effect of vitamin E supplementation on plasma and milk fatty acid profiles in dairy cows. J. Dairy Res. 72:322332. http://dx.doi.org/10.1017/S0022029905000944.

Kiokias, S. N., C. P. Dimakou, I. V. Tsaprouni, and V. Oreopoulou. 2006. Effect of compositional factors against the thermal oxidative deterioration of novel food emulsions. Food Biophys. 1:115-123. http://dx.doi.org/10.1007/s11483-006-9015-2.

Köster, H. H., R. C. Cochran, E. C. Titgemeyer, E. S. Vanzant, I. Abdelgadir, and G. St-Jean. 1996. Effect of increasing degradable intake protein on intake and digestion of low-quality, tallgrassprairie forage by beef cows. J. Anim. Sci. 74:2473-2481.

Labuza, T. P., and L. R. Dugan. 1971. Kinetics of lipid oxidation in foods. Crit. Rev. Food Nutr. (Roma) 2:355-405. http://dx.doi. org/10.1080/10408397109527127.

Lindmark-Månsson, H., and B. Åkesson. 2000. Antioxidative factors in milk. Br. J. Nutr. 84(Suppl. 1):S103-S110. http://dx.doi. org/10.1017/S0007114500002324.

Lu, C. D., N. A. Jorgensen, and L. D. Satter. 1988. Site and extent of nutrient digestion in lactating dairy cows fed alfalfa protein con- 
centrate or soybean meal. J. Dairy Sci. 71:697-704. http://dx.doi. org/10.3168/jds.S0022-0302(88)79608-3.

Lyan, B., V. Azaïs-Braesco, N. Cardinault, V. Tyssandier, P. Borel, M.-C. Alexandre-Gouabau, and P. Grolier. 2001. Simple method for clinical determination of 13 carotenoids in human plasma using isocratic high-performance liquid chromatographic method. J. Chromatogr. B Biomed. Sci. Appl. 751:297-303. http://dx.doi. org/10.1016/S0378-4347(00)00488-6.

Madsen, T. G., M. O. Nielsen, J. B. Andersen, and K. L. Ingvartsen 2008. Continuous lactation in dairy cows: Effect on milk production and mammary nutrient supply and extraction. J. Dairy Sci. 91:1791-1801. http://dx.doi.org/10.3168/jds.2007-0905.

Malpuech-Brugère, C., J. Mouriot, C. Boue-Vaysse, N. Combe, J. L. Peyraud, P. LeRuyet, G. Chesneau, B. Morio, and J. M. Chardigny. 2010. Differential impact of milk fatty acid profiles on cardiovascular risk biomarkers in healthy men and women. Eur. J. Clin. Nutr. 64:752-759. http://dx.doi.org/10.1038/ejcn.2010.73.

Matumoto-Pintro, P. T., H. V. Petit, H. J. Giroux, C. Côrtes, N. Gagnon, and M. Britten. 2011. Effect of flaxseed lignans added to milk or fed to cows on oxidative degradation of dairy beverages enriched with polyunsaturated fatty acids. J. Dairy Res. 78:111-117. http://dx.doi.org/10.1017/S0022029910000853.

Mestdagh, F., B. De Meulenaer, J. De Clippeleer, F. Devlieghere, and A. Huyghebaert. 2005. Protective influence of several packaging materials on light oxidation of milk. J. Dairy Sci. 88:499-510. http://dx.doi.org/10.3168/jds.S0022-0302(05)72712-0.

Micozzi, M. S., E. D. Brown, B. K. Edwards, J. G. Bieri, P. R. Taylor, F. Khachik, G. R. Beecher, and J. C. Smith. 1992. Plasma carotenoid response to chronic intake of selected foods and betacarotene supplements in men. Am. J. Clin. Nutr. 55:1120-1125.

Naziroğlu, M., T. Güler, and A. Yüce. 2002. Effect of vitamin E on ruminal fermentation in vitro. J. Vet. Med. A Physiol. Pathol. Clin. Med. 49:251-255. http://dx.doi.org/10.1046/j.14390442.2002.00418.x.

Nestel, P. J., S. E. Pomeroy, T. Sasahara, T. Yamashita, Y. L. Liang, A. M. Dart, G. L. Jennings, M. Abbey, and J. D. Cameron. 1997. Arterial compliance in obese subjects is improved with dietary plant n-3 fatty acid from flaxseed oil despite increased LDL oxidizability. Arterioscler. Thromb. Vasc. Biol. 17:1163-1170. http:// dx.doi.org/10.1161/01.ATV.17.6.1163.

Nicoli, M. C., R. Toniolo, and M. Anese. 2004. Relationship between redox potential and chain-breaking activity of model systems and foods. Food Chem. 88:79-83. http://dx.doi.org/10.1016/j. foodchem.2003.12.026.

Noll, C. I., and G. C. Supplee. 1941. Factors affecting the gas content of milk. J. Dairy Sci. 24:993-1013. http://dx.doi.org/10.3168/jds. S0022-0302(41)70225-0.

Nousiainen, J., K. J. Shingfield, and P. Huhtanen. 2004. Evaluation of milk urea nitrogen as a diagnostic of protein feeding. J. Dairy Sci. 87:386-398. http://dx.doi.org/10.3168/jds.S0022-0302(04)731781.

Nozière, P., B. Graulet, A. Lucas, B. Martin, P. Grolier, and M. Doreau. 2006a. Review - Carotenoids for ruminants: From forages to dairy products. Anim. Feed Sci. Technol. 131:418-450. http:// dx.doi.org/10.1016/j.anifeedsci.2006.06.018.

Nozière, P., P. Grolier, D. Durand, A. Ferlay, P. Pradel, and B. Martin. 2006b. Variations in carotenoids, fat-soluble micronutrients, and color in cows' plasma and milk following changes in forage and feeding level. J. Dairy Sci. 89:2634-2648. http://dx.doi. org/10.3168/jds.S0022-0302(06)72340-2.

NRC. 2001. Nutrient Requirements of Dairy Cattle. 7th rev. ed. Natl. Acad. Press, Washington, DC.

Oltner, R., M. Emanuelson, and H. Wiktorsson. 1985. Urea concentrations in milk in relation to milk yield, live weight, lactation number and amount and composition of feed given to dairy cows. Livest. Prod. Sci. 12:47-57. http://dx.doi.org/10.1016/03016226(85)90039-9.
Ozen, A. E., A. Pons, and J. A. Tur. 2012. Worldwide consumption of functional foods: a systematic review. Nutr. Rev. 70:472-481. http://dx.doi.org/10.1111/j.1753-4887.2012.00492.x.

Parker, R. S. 1996. Absorption, metabolism and transport of carotenoids. FASEB J. 10:542-551.

Prache, S., A. Priolo, and P. Grolier. 2003. Persistence of carotenoid pigments in the blood of concentrate-finished grazing sheep: Its significance for the traceability of grass-feeding. J. Anim. Sci 81:360-367.

Rock, C. L. 1997. Carotenoids: Biology and treatment. Pharmacol. Ther. 75:185-197. http://dx.doi.org/10.1016/S01637258(97)00054-5.

Saliba, L., R. Gervais, Y. Lebeuf, and P. Y. Chouinard. 2014. Effect of feeding linseed oil in diets differing in forage to concentrate ratio: 1. Production performance and milk fat content of biohydrogenation intermediates of $\alpha$-linolenic acid. J. Dairy Res. 81:82-90. http://dx.doi.org/10.1017/S0022029913000691.

Schweigert, F. J., W. A. Rambeck, and H. Zucker. 1987. Transport of $\beta$-carotene by the serum lipoproteins in cattle. J. Anim. Physiol. Anim. Nutr. (Berl.) 57:162-167. http://dx.doi. org/10.1111/j.1439-0396.1987.tb00024.x.

Sies, H., and W. Stahl. 1995. Vitamins E and C, $\beta$-carotene, and other carotenoids as antioxidants. Am. J. Clin. Nutr. 62(Suppl.):1315S1321S.

Smith, L. M., W. L. Dunkley, and M. Ronning. 1963. Influence of linoleic acid content of milk lipids on oxidation of milk and milk fat. J. Dairy Sci. 46:7-10. http://dx.doi.org/10.3168/jds.S00220302(63)88953-5.

Sundquist, A., K. Briviba, and H. Sies. 1994. Singlet oxygen quenching of carotenoids. Methods Enzymol. 234:384-388.

Ullrich, F., and W. Grosch. 1988. Flavour deterioration of soya-bean oil: Identification of intense odour compounds formed during flavour reversion. Fett/Lipid 90:332-336. http://dx.doi.org/10.1002/ lipi.19880900902.

van den Berg, H., R. Faulks, H. F. Granado, J. Hirschberg, B. Olmedilla, G. Sandmann, S. Southon, and W. Stahl. 2000. Review: The potential for the improvement of carotenoid levels in foods and the likely systemic effects. J. Sci. Food Agric. 80:880-912.

Van Soest, P. J., F. B. Robertson, and B. A. Lewis. 1991. Methods for dietary fiber, neutral detergent fiber, and nonstarch polysaccharides in relation to animal nutrition. J. Dairy Sci. 74:3583-3597. http://dx.doi.org/10.3168/jds.S0022-0302(91)78551-2.

Vargas-Bello-Pérez, E., and P. C. Garnsworthy. 2010. Differential transport of trans fatty acids by bovine plasma lipoprotein fractions: 1. Soya oil and partially hydrogenated vegetable oil. Adv. Anim. Biosci. 1:21 http://dx.doi.org/10.1017/S2040470010001640.

Villeneuve, M.-P., Y. Lebeuf, R. Gervais, G. F. Tremblay, J. C. Vuillemard, J. Fortin, and P. Y. Chouinard. 2013. Milk volatile organic compounds and fatty acid profile in cows fed timothy as hay, pasture or silage. J. Dairy Sci. 96:7181-7194. http://dx.doi. org/10.3168/jds.2013-6785.

Vlaeminck, B., V. Fievez, A. R. J. Cabrita, A. J. M. Fonseca, and R. J. Dewhurst. 2006. Factors affecting odd- and branched-chain fatty acids in milk: A review. Anim. Feed Sci. Technol. 131:389-417. http://dx.doi.org/10.1016/j.anifeedsci.2006.06.017.

Weatherburn, M. W. 1967. Phenol-hypochlorite reaction for determination of ammonia. Anal. Chem. 39:971-974. http://dx.doi org/10.1021/ac60252a045.

Weill, P., B. Schmitt, G. Chesneau, N. Daniel, F. Safraou, and P. Legrand. 2002. Effects of introducing linseed in livestock diet on blood fatty acid composition of consumers of animal products. Ann. Nutr. Metab. 46:182-191. http://dx.doi.org/10.1159/000065405.

Yang, A., T. W. Larsen, and R. K. Tume. 1992. Carotenoid and retinal concentrations in serum, adipose tissue and liver and carotenoids transport in sheep, goats and cattle. Aust. J. Agric. Res. 43:18091817. http://dx.doi.org/10.1071/AR9921809. 